\title{
Standards, Trade Margins and Product Quality: Firm-Level Evidence from Peru
}

\author{
Daniele Curzi ${ }^{\text {a }}$ \\ Monica Schuster ${ }^{\mathrm{b}}$ \\ Miet Maertens ${ }^{c}$ \\ Alessandro Olper ${ }^{1, a, d}$ \\ (a) Department of Environmental Science and Policy, University of Milan, Italy \\ (b) Institute of Development Policy and Management University of Antwerp, Belgium \\ (c) Department of Earth and Environmental Sciences, Division of Bioeconomics, KU Leuven, Belgium \\ (d) LICOS-Centre for Institution and Economic Performance, KU Leuven, Belgium
}

\begin{abstract}
The ongoing debate on whether agri-food (public) regulatory standards are barriers or catalysts to trade is particularly pertinent for developing countries who are often standardtakers. Current evidence on the trade effects of regulatory standards is ambiguous. In this paper, we give a contribution focusing on the firm heterogeneity trade effects of (different) types of agri-food standards, considering firm-level exports from Peru. Particular emphasis is given to standards with different degree of restrictiveness, such as specific trade concerns (STCs) raised on the most stringent NTMs, and to product-quality upgrading. Results show that only the most restrictive NTMs significantly limit agri-food exports for Peruvian firms, affecting the probability to trade, firms' exit and the export volume. Regular SPSs are found to enhance trade. Importantly, we uncovered relevant heterogonous effects of NTMs on firms of different size, showing that only the most stringent standards result in product quality upgrading.

Key words: NTMs, firm-level data, trade margins, product quality.

JEL codes: F12, F14, Q18.
\end{abstract}

${ }^{1}$ Corresponding author: alessandro.olper@unimi.it, University of Milan, Italy. 


\title{
Standards, Trade Margins and Product Quality: Firm-Level Evidence from Peru
}

\begin{abstract}
The ongoing debate on whether agri-food (public) regulatory standards are barriers or catalysts to trade is particularly pertinent for developing countries who are often standard-takers. Current evidence on the trade effects of regulatory standards is ambiguous. In this paper, we give a contribution focusing on the firm heterogeneity trade effects of (different) types of agri-food standards, considering firm-level exports from Peru. Particular emphasis is given to standards with different degree of restrictiveness, such as specific trade concerns (STCs) raised on the most stringent NTMs, and to product-quality upgrading. Results show that only the most restrictive NTMs significantly limit agri-food exports for Peruvian firms, affecting the probability to trade, firms' exit and the export volume. Regular SPSs are found to enhance trade. Importantly, we uncovered relevant heterogonous effects of NTMs on firms of different size, showing that only the most stringent standards result in product quality upgrading.
\end{abstract}

Key words: NTMs, firm-level data, trade margins, product quality.

JEL codes: F12, F14, Q18. 


\section{Introduction}

In recent decades, the use of agri-food regulatory standards addressing safety, quality and environmental concerns has increased substantially, triggering growing attention to their trade and welfare effects (see Beghin, Maertens and Swinnen 2015; Santeramo and Lamonaca 2019, for recent surveys). However, understanding the economic impacts of these policy measures is not trivial. On the one hand, many regulatory standards are set to address externalities and market failures and, as such, they can be welfare enhancing or lead to quality upgrading and increased market access (Xiong and Beghin 2014; Manova and Yu 2017; Cadot, Gourdon and van Tongeren 2018). On the other hand, regulatory standards can limit trade and so are often referred to as non-tariff measures (NTMs). The problem with regulatory standards is the conceptual difficulty of knowing whether a particular regulation serves the public or protectionist's interest — and both motives are often combined in a single measure (Baldwin 2000; Swinnen 2016).

This is particularly relevant for developing countries (Murina and Nicita 2017). First, because they are typically international "standard-takers" and have more limited capacity to meet the requirements set by public regulatory standards because of a 'standard divide', i.e. a difference in implicit quality and safety norms between countries with different income levels. Second, NTMs are more abundant in product groups for which developing countries often have a comparative advantage, such as agricultural and food products. Finally, it has been suggested that through quality upgrading and reducing information asymmetries, regulatory standards can stimulate in particular exports from developing countries (Jaffee and Henson 2005; Maertens and Swinnen 2009).

In this paper, we study the trade and economic effects of NTMs, exploiting a rich firmlevel dataset on agri-food exports from Peru. This country is an ideal case study for investigating this issue. During the last two decades, Peru has been involved in a process of 
export diversification, shifting from traditional commodities (coffee, cocoa, and cotton) towards fruit, horticulture and processed foods. This has triggered an impressive growth in its export performance. It is worth noting that these products are precisely those where public regulatory standards are more concentrated, especially in high-income countries. While some recent studies report positive impacts on employment conditions and worker empowerment (see, e.g., Schuster and Maertens 2016, 2017), how these gains have been transmitted to poorer farmers has raised concern, particularly regarding the lack of opportunities for integrating small-scale farmers in value chains for horticultural exports (see Schuster and Maertens 2013; World Bank 2017). ${ }^{1}$

We use firm-level customs data for the 2000-2014 period and estimate the impact of regulatory standards on individual firms' export decisions, considering several different trade margins of adjustment. In particular, we study how firms of different size react to the introduction of new restrictive standards in the destination market, and we give particular emphasis to the firms' pricing behavior and to the extent to which a new regulatory standard affects the quality and quality-adjusted prices of exported goods. It is worth mentioning that we work with the entire portfolio of different regulatory standards. In particular, we first exploit a rich dataset on specific trade concerns (STCs) raised at the WTO by countries affected by (restrictive) sanitary and phytosanitary standards (SPSs). Second, we use information from an original dataset from 1995 onwards based on all NTMs notified to the WTO, such as emergency and regular SPSs, technical barriers to trade (TBT) and border NTMs, such as import quota, price control and antidumping measures.

Quality is estimated at the firm-product-destination level, by relying on the approach developed by Khandelwal, Schott and Wei (2013). This methodology is based on the

\footnotetext{
${ }^{1}$ Peru presents evidence that when large numbers of small-scale producers have succeeded in penetrating international markets, usually they have focused on commodities with more modest market requirements, such as cocoa, coffee, and bananas. This happened by "de-commodify" traditional products through quality differentiation, exploiting also private standards, such as fair trade (see World Bank 2017).
} 
estimation of a demand function, and relies on the presumption that, conditional on price, products exported in higher quantity are assigned higher quality. By working at the firm level, our analysis emphasizes the heterogeneous effects of regulatory standards across differentsized exporters.

Using a difference-in-difference research design and addressing potential endogeneity problems of restrictive standards to international trade, key findings show that NTMs affect agri-food exports of Peruvian firms differently depending on their restrictiveness and the size of exporting firms. The trade effects are negative for both the extensive and intensive margin for the most stringent standards targeted by STCs, and less so for border NTMs and emergency SPSs. The most restrictive standards are particularly burdensome for smaller firms. Controlling for restrictive SPSs and border NTMs, we find that TBTs and especially regular SPSs, that represent the bulk of agri-food standards, often increase market access by affecting positively both the extensive and intensive trade margin. Importantly, only the most stringent food standards induce a process of quality upgrading, and this is particularly strong for surviving smaller firms. All these findings have interesting policy implications.

Our paper is related to two main streams of the current literature on trade and agri-food standards. First, while many published studies investigate the trade effect of regulatory standards (see Santeramo and Lamonaca, 2019), the evidence on the effects of regulatory standards on different trade margins at the firm level, especially in developing countries, is rare. Together with a recent contribution by Fernandes, Ferro and Wilson (2019), our study is one of the first evaluations of how (different) regulatory standards affect exports by firms in a developing country, focusing on agri-food trade. In line with Fernandes, Ferro and Wilson (2019), we compare regulatory standards with, a-priory supposed, different stringency levels, which we consider an important strategy to better understand the complex patterns of trade effects of NTMs. From this point of view, we extend the contribution of Fontagné et al. 
(2015), who are the first to use SPS specific trade concerns data. The main advantage of these data is that STCs can be considered de facto as restrictive trade measures, being raised by countries to the WTO because they represent a trade hurdle. Fontagné et al. (2015), by matching WTO data on the STCs with French firms' custom trade data, investigated the effect of restrictive SPSs on different trade margins. They find that STCs reduce both the extensive and intensive trade margins, and that this effect is stronger for smaller exporting firms. Our paper adds to the evidence provided by Fontagné et al. (2015) in three main respects. First, we focus on a developing country, Peru, where firm level exports should significantly be more affected by restrictive SPS. Second, we combine information on STCs with all NTMs notified to the WTO, such as SPSs, TBTs and border NTMs. This may be an important extension, because different NTMs may have different effects on firms' export decision, and omitting them can raise a potential omitted variables bias. Finally, and perhaps more importantly, we extend the analysis of different NTMs considering also their impact on (firm-level) product quality and quality-adjusted price, a crucial issue that allows a better understanding of the potential welfare effect of NTMs. Moreover, quality differentiation is particularly relevant in high-value agricultural export sectors - horticultural produce is for example often graded in different quality classes - and plays an important role in accessing export versus domestic markets for firms in developing countries (Swinnen and Vandeplas 2011).

Our study is the first to examine the effect of STCs and different types of NTMs on price, quality and quality-adjusted prices at the firm level. Considering price and quality is particularly relevant for developing countries. This is because in these countries intrinsic quality norms are less demanding and the quality upgrading impact of standards might be largest, as it is argued-without evidence at the firm level—in the debate on the impact of agri-food standards for developing countries (e.g. Jaffee and Henson 2005; Beghin, Maertens and Swinnen 2015). In addition, by working at the firm level and exploiting heterogeneous 
effects across firms, we can explore to what extent standards actually discriminate against small and less productive firms and, indirectly, how they affect competition in the destination markets. From this perspective, our findings appear in line with the intuition of Asprilla et al. (2019). According to these authors, contrary to tariffs that reduce competition (and market power) of foreign firms through classic rent-shifting effects, NTMs alter competition by reinforcing the market power of surviving exporting firms, and are detrimental especially for smaller firms.

The remainder of the paper is organized as follows: the next section (Related literature and conceptual background) summarizes the relevant literature on NTMs, trade and quality upgrading, followed by a conceptual discussion on the impact of NTMs. The third section (Data) presents firm-level export data of Peru and the NTM datasets. The section (Empirical Strategy) discusses the econometric model and the identification strategy. The fifth section summarizes and discusses the results. The final section concludes and draws some policy implications.

\section{Related literature and conceptual background}

There is a growing body of literature on the link between (agri-food) regulatory standards and trade flows at the import and export level, and this feeds the debate on NTMs and their economic effects. Most evidence comes from gravity models, and often indicates a trade reducing effect of NTMs. ${ }^{2}$ For example, in the recent meta-analysis of Santeramo and Lamonaca (2019), 33 out of 62 studies find a negative trade effect of standards. Many of these papers focus on Maximum Residue Levels (MRLs) in agri-food products (e.g. Wilson and

\footnotetext{
${ }^{2}$ Academic articles on the trade effect of NTMs increased substantially in the last decades. Santeramo and Lamonaca (2019) in their survey documented 14 studies published up to 2000, which became 140 to 2017. Clearly, this positive trend parallels the explosion of SPSs and TBTs notifications at the WTO (see WTO 2012; Olper 2016). A parallel trend is related to the growth of private and voluntary standards set by business groups and large retailers finalized, among other things, to better coordinate modern global value chain. For a discussion of their effect on developing country firms and trade issues see, among others, Nadvi (2008) and Vigani and Olper (2014).
} 
Otsuki 2003; Disdier and Marette 2010; Ferro, Wilson and Otsuki 2015), a measure that accounts for the restrictiveness of standards. However, several other papers find a negative trade effect of standards when overall SPS and/or TBT measures are included (e.g. Disdier, Fontagné and Mimouni 2008; Dal Bianco et al. 2016; Arita, Beckman and Mitchell 2017), a result that holds in particular when low- or middle-income country exporters are considered. Interestingly, about $1 / 3$ of studies surveyed by Santermo and Lamonaca (2019) find mixed trade effects of standards (e.g. Wilson and Otsuki 2004; Xiong and Beghin 2014), a results that is however not linked to a particular type of standard used in the empirical analysis. From this summary evidence, it clearly emerges that simple generalizations on the trade impact of standards are particularly difficult (Swinnen 2016).

Literature studying the effect of trade barriers on export flows has developed in the last years starting from the predictions of firm heterogeneity trade models, according to which the introduction of a trade barrier induces higher costs, which not all firms can cope with. These predictions suggest that only the most productive firms can overcome these costs, and the least productive firms are forced to exit the export market (Melitz 2003; Chaney 2008; Melitz and Ottaviano 2008). Within this firm heterogeneity trade literature there is a growing theoretical and empirical emphasis on the key role of product quality in affecting firms' export performance (e.g., Verhoogen 2008; Bellone et al. 2009; Crozet, Head and Mayer 2012; Kugler and Verhoogen 2012; Hallak and Sivadasan 2013; Feenstra and Romalis 2014). However, only few papers investigated the relation between trade policy and product quality. For example, Amiti and Khandelwal (2013) showed that US lower tariffs induce quality upgrading, but only for products close to the technological frontier. Similarly, Curzi, Raimondi and Olper (2015) confirm these findings for the EU agri-food markets. Gaignè and Laure (2016) developed a firm heterogeneity model to study how stricter national (quality) public standards affect domestic and foreign firms. Interestingly, they showed that higher 
quality standards benefit highly productive foreign firms, which gains from the qualityinduced exit of less productive domestic and foreign firms. However, no empirical studies to date have explicitly investigated how different kinds of public standards in the destination market affect the quality of export produce and quality-adjusted prices for firms in developing countries. $^{3}$

Product quality is often acknowledged as a pre-condition for success in international markets and for economic development (Amiti and Khandelwal 2013), especially in agri-food sectors where the disparity in product quality between local and export markets can be very large (Beghin, Maertens and Swinnen 2015; Swinnen and Vandeplas 2011). Quality may be particularly critical for exporting firms in developing countries that have to comply with the high quality and safety requirements of richer countries to fully integrate in global markets (see, e.g., Brooks 2006). However, the compliance with standards can be a means for quality upgrading, in particular in developing countries. This is because changing consumers demand over the last decades has reshaped agri-food markets competition from being mostly pricebased to be increasingly focused on quality (Curzi, Raimondi and Olper 2015). This is due on the one hand to the growing consumers' concerns toward food safety that has been triggered by a number of food scares, despite the consistent progresses in technology (Caswell and Mojduszka 1996; Grunert 2005; Henson and Reardon 2005). On the other hand, when assessing product quality, consumers increasingly attach higher importance to products' attributes that in most of the cases are credence attributes. These include for instance the way they are produced (e.g. organic production or the attention toward issues such as animal welfare or environmental sustainability) or their intrinsic properties and food safety attributes (e.g. the maximum residue limit of the pesticide) (Henson and Reardon 2005). In this framework, standards represent a means for public authorities to improve the level of

\footnotetext{
${ }^{3}$ An exception is the work of Olper, Curzi and Pacca (2014) that, however, focused on the impact of EU voluntary, and not public, standards and the import quality upgrading.
} 
regulation requirements in the food system that allows improving food safety and quality. Moreover, standards' requirement for improving product attributes provide a fundamental contribution in meeting consumers' demand for product differentiation. All this suggests that there could exists a strict link between product quality and agri-food standards.

Several studies show how standards may lead to agri-food trade expansion by raising the quality of exported products and thereby improving their competitiveness (see $\mathrm{Hu}$ and Lin (2016) on China; Jaffee and Henson (2005) on Kenya and Peru; Maertens and Swinnen (2009) on Senegal; and Olper, Curzi and Pacca (2014) on EU imports). However, strict food safety standards can pose a threat to smallholder firms by creating new requirements for knowledge about food safety, additional investment in equipment and food safety systems, and more intensive linkages between producers and the buyers of their products (IFAD, 2017).

To shed some light on the trade and welfare effects of NTMs, it is extremely important to assess their heterogeneous effects at firm level, namely on firms of different size and productivity. To our knowledge, only a handful of studies have analyzed how regulatory standards affect trade at the firm level (e.g. Chen, Wilson and Otsuki 2008; Reyes 2011 Fontagné et al. 2015; Fernandes, Ferro and Wilson 2019), and no one has addressed the link between quality and quality-adjusted price and the restrictiveness of food standards. From this perspective, this work provides an innovative contribution to this literature with a focus on agri-food trade in a developing country, with more comprehensive measures of NTMs and with analysis of their trade effects as well as price and quality effects.

\section{Theoretical considerations}

The surge of agri-food standards, such as sanitary and phytosanitary measures, parallel a concomitant worldwide reduction in tariffs. Yet, it is important to emphasize that the effect of the former are significantly different from the latter. Tariffs represent taxes on imports, and as 
such, they induce a cost wedge between domestic and foreign firms. Conversely, while food standards may affect imports similarly as tariffs (i.e. reducing trade), they could also act as a market-creating measure, for example by increasing consumer information. Clearly, depending on which of these two contrasting effects (i.e. trade cost vs. demand-enhancing effect) will prevail, the trade effect of a SPS measure could be both positive or negative (see Xiong and Beghin 2014; Cadot et al. 2018).

Our analysis aims at better understanding the firm-level effects of most restrictive SPS that are subject to STCs and various types of NTMs on different margins of trade adjustment - i.e., extensive, intensive, price and quality - considering potential heterogeneous effects across firm size. According to extensions of the Krugman (1980) monopolistic competition trade model, which incorporates firm-heterogeneity (e.g. Melitz 2003; Chaney 2008; Bernard, Redding and Schott 2012), the fixed cost component of a regulatory standard is expected to mainly affect the extensive margin of trade, whereas the variable cost component is expected to affect both the extensive and intensive margins of firms' exports. A new restrictive NTM likely imposes both additional fixed costs of entry (e.g., investment in new equipment and adjustment of production methods) and variable costs (e.g., costlier inputs) in those markets/sectors maintaining this measure. SPS measures affected by STCs are by definition trade restrictive, therefore in accordance with existing evidence (see Fernandez et al. 2016) it is expected that, on average, they lead to firm market exit and to negatively affect Peruvian firms' agri-food exports on the extensive margin of trade. Higher variable costs negatively affect the intensive margin of firm trade, unless higher fixed trade costs sufficiently foster firms' exit from a destination market, such that the export volume and value of incumbent firms increase. Hence, a-priory, the impact on the intensive margin, conditional to export, is ambiguous. Importantly, and in line with firm-heterogeneity models by Arkolakis (2010), and Spearot (2013), we expect the negative effect of restrictive standards on firms' trade margins 
to intensify as firm size decreases, because smaller firms tend to be more responsive to trade shocks.

The overall trade effect of other less restrictive NTMs, such as "regular" SPSs and TBTs, is more ambiguous. Increasing costs could be compensated by increased market access due to quality upgrading and/or more consumers' information. From this perspective, the trade effect of NTMs can be either positive or negative, as generally reported in the relevant literature (see Xiong and Beghin 2014; Beghin, Maertens and Swinnen 2015; Cadot et al. 2018).

Expectations with respect to the impact of regulatory standards on price, quality and quality-adjusted price, are less clear cut and often ambiguous. How most restrictive SPS measures that are subject to STCs — which are notoriously linked to quality, health and safety requirements - may affect quality upgrading, and how this process differs across countries maintaining these measures with different income levels and across firms of different size, has been rarely studied empirically. It is intuitive to expect that new (restrictive) SPS measures increase both price and quality. Increased fixed and variable costs may be passed on to consumers and lead to increased prices. In addition, consumers in importing countries may be willing to pay a "quality premium" for products that meet specifications for quality and safety covered in the product standard. On the other hand, to the extent that fixed costs are affected, firm-heterogeneity trade models suggest that new restrictive SPS measures may lead to a redistribution of market shares among firms (both domestic and foreign) and affect firms' price and quality choices depending on their pricing strategy, which is a-priory unknown. Surviving firms can decide to upgrade the quality of their export products and/or to capture the additional rents.

Empirical evidence shows that, conditional on firm size, exporters sell higher quality products and charge higher prices, as well as pay higher input prices and higher wages (e.g., Verhoogen 2008; Curzi and Olper 2012; Kugler and Verhoogen 2012). Hence, larger firms 
likely need to increase their production costs less than smaller firms in order to adapt their export products to the new (quality) standards, and larger firms tend to produce, on average, higher quality goods, which is in line with the so-called quality sorting model (Crozet, Head and Mayer 2012). At the same time, restrictive SPS measures can alter competition in the destination market (Abel-Koch 2013; 2016; Asprillia et al. 2018) inducing the exit of the less productive (domestic and foreign) firms and/or firms producing lower quality goods, and thus reducing the scope for quality differentiation. In this new market environment, larger exporters (and/or surviving firms), may respond by increasing price more (and quality less) than smaller exporters (Fontagné et al. 2015). However, other mechanisms could be at work. One of the few published paper that explicitly studied the impact of restrictive (quality) standards on firms' export behavior and market structure is the one by Gaigné and Laure (2016). These authors, by introducing vertical differentiation in a firm heterogeneity trade model, show that as quality standards increase, some domestic and foreign firms will exit from the market, which leads to reallocation of market share towards more productive firms, thus raising market concentration. In addition, the reduction in factor demand by the lowquality foreign (and domestic) firms will also benefit the high-quality foreign firms, thus eventually inducing a process of quality upgrading.

Finally, additional insights about mechanisms through which standards may affect quality, can be find from the literature on minimum quality standards. Models of Shapiro (1983) and Leland (1979) suggest that, on the one hand prices are expected to grow due to the increased costs of producing higher quality products meeting the standards. On the other hand, an increase in price may be motivated by the reduced competition in the market imposing the standard, due to the decision of firms that cannot address the standard to leave the market. Thus, for some group of consumers could be worse off as the result of the new 
standard, because the imposition of the standard my lead to an increase in prices and a reduction of (preferred) varieties.

A model where the introduction of a quality standard unambiguously induce (firm) quality upgrading and increase welfare, is the one of Ronnen (1991), where firms face quality-dependent fixed costs and compete in both quality and price. Within a qualitydifferentiation monopolistic competition model (Shaked and Sutton 1982) he shows that the introduction of a (minimum) quality standard can induce an increase in the level of price competition, because standards limit the range in which firms can differentiate qualities. Hence, even though the high-quality producers satisfy the standard in absence of a regulation, after the introduction of the standard they will have an incentive to raise quality. This is because the compliance with the public standard, leads low-quality (surviving) firms to improve their quality. Therefore, the difference in quality between firms reduces after the introduction of the standard. This causes an increase in price competition and, as a consequence, a reduction of quality-adjusted price. In this new competitive environment, high-quality firms try to escape from the intensification of price competition, by further improving their quality.

In our framework, the use of measures of price, quality and quality-adjusted price at the firm level, allows us to empirically disentangle the extent to which the effects of new, trade restrictive, regulatory measures induce surviving exporting firms to charge higher prices and/or quality upgrading, and to reveal effects for different-sized exporters. In addition, because the firm pricing behavior is also related to the level of competition in the destination market, we can indirectly learn new insights about how STCs and different NTMs alter the level of competition there. This implies a significant advancement in the understanding of the role of standards in affecting firms' trade outcomes with respect to previous analyses. 


\section{Data}

To study the effect of STCs and other NTMs on agri-food exports from Peru, this paper combines three databases: (i) a firm-level customs dataset on Peruvian agri-food exports for 2000-2014; (ii) a recent WTO database on STCs extended to 2016, concerning SPS measures; and (iii) a new database on NTMs notified to the WTO, compiled from the Integrated Trade Intelligence Portal (I-TIP). Finally bilateral tariff data are obtained from the UNCTAD-Trains database.

\section{Peruvian Firm Data}

Firm-level export data are provided by Peruvian Customs (SUNAT) for the period 20002014. The Peruvian customs data provide, for the considered period, information on worldwide export flows for more than 9,000 firms in the agri-food sectors. The data include exporter identity (name and tax identification number), identification of the exported item (at HS 10-digit level), destination country for each trade flow and shipment port, as well as the quantity and FOB value of each shipment. Specifically, we focus on agri-food chapters 2-24 of the HS code, for which SPS measures have been shown to be most relevant. ${ }^{4}$ For the considered period, this represents $95 \%$ of Peruvian total agri-food exports. There are 7,263 exporting firms, shipping to more than 180 countries.

The Peruvian agri-food export sector is particularly dynamic and has steadily grown since the mid-1990s (Freund and Pierola 2010; Schuster and Maertens 2015; World Bank, 2017). This growth is mainly driven by non-traditional agricultural exports, led by asparagus, and more recently followed by grapes, mangos, paprika, avocado and artichokes. Traditional exports like coffee and tea (in chapter 9 of the HS code) represent barely $9 \%$ of all agri-food trade, while vegetables and fruit exports, in either fresh (chapters 7 and 8) or prepared form (chapter 20) represent $39 \%$ of all agri-food trade in the observed period. Tables A1 and A2 in

\footnotetext{
${ }^{4}$ About $94 \%$ of SPS STCs raised during 1995-2016 refer to the agri-food sector.
} 
the Appendix, report a snapshot of Peruvian agri-food exports across products and destination markets.

The customs' data we use do not include more specific information on the export firms in our sample. Other firm-level research has dealt either with Peruvian's main export crop, asparagus (Schuster and Maertens 2013; 2015) or Peru's major export sectors including agriculture (ITC, 2012). Results from these studies indicate that the vast majority of exporters are fully Peruvian owned; only few firms reported partial foreign ownership (mainly Chilean, Spanish, Danish or US capital). The majority of surveyed exporting companies had been in operation for over five years and around one third of all asparagus firms are vertically integrated, with production, post-harvest handling and exporting controlled by the company. The majority of horticultural products are exported in a processed and ready-to-consume form, implying that the added-value from product sorting, handling and packaging stays within the national borders.

Finally, it is worth noting that the growth of Peruvian firms' exports has mainly concerned agri-food sectors that are particularly demanding in terms of restrictive public (and private) regulatory standards in the destination markets. Quality plays an important role in these export sectors. For example, for asparagus, Peru's flagship export product, quality relates to size, color, taste (especially bitterness), texture (especially fiberiness), and shape (especially crooked tips); and is influenced by pre- and post-harvest factors (FAO 2011; O'Brien and Diaz Rodriguez 2004). Especially agronomic management and harvesting practices and temperature during cold storage, play an important role in determining quality aspects. Peru applies a basic quality classification into four quality classes ('extra quality', 'first quality', 'second quality' and 'less than second quality' - with the last class not suitable for export) set by the Office for the Promotion of Peruvian Exports (PROMPEX). At the same time, Frio Aéreo, a non-profit association of Peruvian producers and exporters dealing with 
export logistics, monitors temperature in asparagus at the point of shipment in order to improve the cold chain. Exports of the 'extra quality' and 'first quality' asparagus have increased (e.g. from 60 million $\mathrm{kg}$ in 2001 to more than 70 million $\mathrm{kg}$ in 2003) while exports of 'second class' asparagus are decreasing (e.g. from about 40 million $\mathrm{kg}$ in 2001 to slightly more than 30 million kg in 2003) (O'Brien and Diaz Rodriguez 2004). FAO (2011) reports that one of the important factors behind the success of Peruvian agri-food exports, has been the recognition that this success depends on the quality and safety of produce. From this perspective, two main questions arise. First, why this positive export performance and quality upgrading occurred particularly in these sectors? Second, are small producers, and to what extent, part of this successful story? Our analysis provides interesting insights to better answer these important research questions.

\section{Specific Trade Concerns}

The STC database was recently released by the WTO and refers to concerns that are raised, in either written or oral form, by individual WTO members in the SPS or TBT committees. Members use these committees to discuss issues related to specific SPS (TBT) measures that are maintained by other member countries and which might significantly affect trade. The issues are denoted as STCs. Each STC provides information on the (i) country raising the concern and the country imposing the measure, (ii) year of the concern, (iii) product of concern at the HS 4-digit level and (iv) type of measure and subject of the concern. In this paper, we specifically focus on STCs raised in the SPS committee, because they are most relevant for the agri-food trade (Grant and Arita 2017). ${ }^{5}$

It is worth mentioning that data on SPS STCs provide information on the eventual date of the resolution of the concern, if any. However, as reported by Grant and Arita (2017) in a

\footnotetext{
${ }^{5}$ Grant and Arita (2017) report for the period 1995-2015 more than 400 SPS STCs raised on agri-food products and "only" 172 STCs raised in the TBT Committee.
} 
relevant survey on NTMs and STCs in particular, in many cases concerns remain unresolved or the resolution is not reported. ${ }^{6}$ Therefore, in our analysis we do not consider information on the final resolution of the concerns. Note however that, our results are not sensitive to this choice, as the results remain stable in either case.

With respect to the released version, we extended and updated the data up to the last year available (i.e. 2015). During 1995-2015, about 400 STCs were raised on agri-food products against an SPS measure imposed by one or more trading partners. Figure 1 shows the number of SPSs targeted by a STC raised each year in the period considered in this analysis (i.e., 2000-2014): $35 \%$ of the concerns relate to animal health, $39 \%$ to food safety and $19 \%$ to plant health. The issues raised in this period were resolved in $25 \%$ of all cases and in $5 \%$ were only partially resolved. It is important to note that each STC can be raised by one country, but also more than one if the same concern is taken up by an additional member in the assembly. In the analysis we focus on all SPS-STC data at the maintaining country-product level, assuming that once a country maintains a measure that is considered restrictive for trade by one or more countries, this would be true also for other countries exporting the same product. This is consistent with the non-discrimination rule of the WTO, and is totally supported by the results.

A final issue that needs to be mentioned when dealing with STCs data concerns their timing, namely that a certain STC may refer to a measure imposed by a country one or more years before the concern is raised, ${ }^{7}$ or, in contrast, it may be raised on a draft legislation. ${ }^{8}$ However, as the former case (i.e. delay in STC notification) is much more recurrent than the latter, the STC data may sometimes refer to measures that are likely to act as a trade hurdle years before the concern is raised. From this perspective, it is important to keep in mind that,

\footnotetext{
${ }^{6}$ Grant and Arita (2017) report the weighted average of successful resolution to be less than 50 percent. However, there are several examples of concerns that are likely resolved but without an official resolution.

${ }^{7}$ This may occur for different reasons, e.g. an STC may be raised first orally at the WTO, or a concern might not be raised promptly as the SPS committee meetings are limited in time and scope.

${ }^{8}$ An example is STC 383, that refers to the EU proposed regulation on endocrine disruptors.
} 
though this could induce measurement errors, we are on the safe side because, potentially, our analysis will under-estimate the true STC effect, as our STC variable will pick up a residual (or longstanding) effect of a shock that occurred back in time. Having said that, there is no real way to account for this issue, as for instance the use of lagging or leading variables may create a further bias in the analysis.

\section{Other Non-Tariff Measures}

To develop a more comprehensive measure that accounts for the effect of all NTMs, we built a new dataset based on the WTO I-TIP notification data. The database provides information on NTMs notified by WTO members, including TBTs, SPSs and an array of border NTMs such as antidumping and countervailing measures, tariff rate quotas, quantitative restrictions, safeguards and export subsidies. ${ }^{9}$ Each notification reports data on the notifying importing country, the affected product at the HS 4-digit level and the type of notified NTMs. Notifications do not have a bilateral dimension. NTMs tend to be enforced unilaterally by the importing country and enforced upon all exporting countries of a certain HS tariff line. We consider all notifications that affect at least one of the agri-food product categories exported by Peru during 2000-2014. In this time, an average of 585 new NTMs were notified each year (figure 2): ${ }^{10}$ around $59 \%$ related to SPS, $23 \%$ to TBT measures and $10 \%$ to border NTMs. ${ }^{11}$ For each product-market we construct an indicator for the number of distinct NTMs that are in effect and an indicator which is equal to 1 if at least one NTM is in

\footnotetext{
${ }^{9}$ NTMs refer to mandatory measures that are imposed by countries and that have to be respected by trading partners aimed at exporting their products there. Data provided by the WTO allows only to distinguish between SPS (regular and emergency), TBT and border NTM. A further classification in a limited number of meaningful mutually exclusive categories based on their content is complicated, as in most of the cases NTMs have wide objectives, that are frequently shared by different measures.

${ }^{10}$ As shown in Figure 1 and Figure 2 there exist different patterns over time in the evolution of both SPS STCs and NTMs. However, the analysis of this phenomenon and of the reason behind such differences in the imposition of NTMs over time is out of the scope of this paper. Note, however, that our three-way fixed effects allow to fully control for potential shocks occurring in the destination countries at the product level over time.

${ }^{11}$ Survey results by the International Trade Center reveal that NTMs represent a burden to Peruvian exporters: $41.9 \%$ of firms stated that they are affected by NTMs and almost half of the firms in the agri-food sector reported facing NTMs, where technical regulations (49\% of all cases) and conformity assessments (32\% of all cases) proved to be the most pressing issues for exporters (ITC 2012).
} 
effect in a given year in each HS 4-digit product line. An interesting feature of the dataset is that its richness allows a further distinction between "emergency" and "regular" SPSs. Because the SPS Agreement defines "emergency" measures as cases "where urgent problems of health protection arise or threaten to arise" for the WTO Member implementing the measure, it is clear that they should be, a-priory, more trade restrictive at least in comparison to "regular" SPSs. So, depending on their product and export markets, individual export firms within Peru can be affected differently by SPSs in effect in a given year.

Table 1 shows summary statistics of the key variables of interest. Figures show that restrictive SPSs affected by STCs are present in $45 \%$ of product-destination tariff lines covered by Peruvian agri-food exports. SPSs and TBTs cover about $78 \%$ of productdestination lines and so are the most important regulatory standards, and border NTMs cover $35 \%$. The large majority of SPS measures are regular SPSs $(76 \%$ of product-destination lines), and emergency SPSs account for only about 3\%.

\section{Empirical strategy and identification issues}

We study the trade effect of STCs and other NTMs on firms' exports, using the following baseline equation, estimated through ordinary least squares (OLS) regression: ${ }^{12}$

$$
\begin{aligned}
& y_{f, h, j, t}=\beta_{0}+\beta_{1} S T C_{h, j, t}+\beta_{2} N T M s_{h, j, t}+\beta_{3} \log (\text { size })_{f, t-1}+\beta_{4} \log (\operatorname{size})_{f, t-1} * \\
& S T C_{h, j, t}+\gamma_{n} \mathrm{X}_{f, h, j, t}+\theta_{h s 2, j, t}+\varphi_{f}+\varepsilon_{f, h, j, t}
\end{aligned}
$$

\footnotetext{
12 "Note that our main equation (1), though does not look like a standard gravity model, is still based on a bilateral (firm-level) trade equation that, together with our set of firm and country-sector-time dummies, make the model close to a standard gravity equation. Yet, a key difference here is the use of very disaggregated custom data at the firm-product level, that do not provide any information on the activity of domestic (i.e. not exporting) firms. As a result, the use of methodologies that are commonly employed to deal with the zero trade issue in a gravity model framework (e.g. Poisson pseudo-maximum likelihood estimation), and any analysis that would allow for instance to account for firm's selection into the export market, is prevented among other things, by the lack of information on domestic firms. This is the reason why, as in previous studies using custom data (see Fontagné et al. 2015; Fernandes et al. 2019), we do not implement estimation methods to account for selection bias (e.g. Heckman style approach)."
} 
where $y$ is the dependent variable for firm $f$, exporting a product $h$ (HS 4-digit) to country $j$ at time $t ; S T C$ and NTMs are indicator dummies for the presence of a regulatory standard at HS 4-digit level; $\log ($ size $)$ is a firm-level measure to capture the heterogeneity of the effects; $X$ is a vector of other controls including mainly bilateral tariffs (aggregate at HS 4-digit level as simple average) and other proxies for firm size, which are discussed below; finally $\theta_{h s 2, j, t,} \varphi_{f}$ and $\varepsilon_{f, h, j, t}$ are HS 2-digit-destination-time fixed effects, firm level fixed effects and the independent and identically distributed error term, respectively.

The dependent variable, $y$, represents alternatively (i) a dummy variable for firms' extensive margin, which accounts for firms' export of a given product in a given market, (ii) a dummy variable accounting for firms' exit from a product-country pair market, ${ }^{13}$ (iii) firms' intensive trade margin, namely the (log) value of firm export of a product $h$ to a destination market $j$ at time $t$; and alternatively (iv) firms' export (log) price, expressed as unit value (i.e., the ratio between product export value and quantity), (v) quality and (vi) quality-adjusted price for each product-market-destination level.

The last two variables are obtained through the estimation of product quality at the firmproduct level, using the methodology of Khandelwal, Schott and Wei (2013). ${ }^{14}$ Quality is estimated from a demand function using data on firms' export unit value and export quantity, by relying on the following intuition: "conditional on price, a variety with a higher quantity is assigned higher quality" (2013, p. 2187). In our specific case, if we take for instance two firms exporting a product belonging to the same product category (e.g. 0709200000 asparagus) in a given destination country (e.g. United States) at the same price (e.g. unit value equal to $2 \$ / \mathrm{Kg}$ ), the one exporting that product in higher quantity is assigned higher quality.

\footnotetext{
${ }^{13}$ Our extensive trade margin measures the probability of a firm to export a product in a destination market. In order to do that, we assign a value of one to firms' positive product-destination trade flows and a value of zero for the years before when no trade occurred. Conversely, we measure firms' probability of exit from a given product-market when firms ceased to export there but having exported the year before.

${ }^{14}$ Note that, for comparability purpose, we performed our quality estimations separately for each product (HS -4 digit)-destination market, so that quality estimation at the firm-product (HS 10-figit) level can be compared within that market.
} 
Moreover, this methodology allows decomposing firms' (FOB) export prices in their quality and quality-adjusted-price components. A detailed discussion on the motivation for using this quality measure in our context and the underlying methodology, is reported in Appendix A.

The main variables of interest in equation (1) are STC and NTMs. STC is a dummy variable taking the value of 1 in those importing product-country pairs (HS 4-digit) where a specific trade concern is raised by one or more countries to the WTO (and zero otherwise). The term NTM includes three different dummy variables, which enter the model separately, and account for SPSs, TBTs and border NTMs, respectively. These dummies take the value of 1 in those importing product-country pairs (HS 4-digit) where the respective NTM is notified to the WTO (and zero otherwise). ${ }^{15}$ The SPS variable is further split by notification requirement to disentangle the effect of regular vs. emergency SPSs. The combination of the STC and NTM dummies in the analysis is an important contribution, as it allows testing whether the effect of STC still holds after controlling for (other) NTMs and to compare effects of standards with different stringency levels. ${ }^{16}$

In order to assess whether standards have heterogeneous effects across firms, we control for (lagged) firm size, expressed as logarithm of the total value of exports of a firm in a given year, irrespective of the product and market destination. This allows us to control for the heterogeneous effect across firms in terms of their productivity, as there is wide consensus in the trade literature about the association between firms' total exports and their productivity

\footnotetext{
${ }^{15}$ It is noteworthy that a STC does not refer to an exclusive NTM, as STCs can refer either to one specific NTM or to a group of NTMs imposed by a country. Moreover, STCs can refer to measures imposed by countries that have been not notified to the WTO, but that de facto act as NTMs. STCs can also refer to customs procedures (e.g. excessive delay in products inspections). From this perspective, there is not a perfect overlap of STC and NTM data in the WTO database. For an in depth discussion about STCs classification, see Grant and Arita (2017).

${ }^{16}$ Tables in the text present the results obtained by introducing all the different NTM variables as dummies. In the Appendix (Tables A5 and A6) we present the results obtained using the (log) number of NTMs, and the results are consistent with those presented in the main text. Note that, the same robustness check has not been carried out for SPS STCs. This is because they often do not refer to a single SPS measure or to an actual SPS measure imposed by a country, and because we do not consider the SPS STCs time dimension for the reasons explained above. Therefore, a precise computation over time of the cumulative number of SPS STCs active for a product in a given country destination is not possible.
} 
(Mayer and Ottaviano 2008; Bernard, Redding, and Schott 2012). ${ }^{17}$ To control for heterogeneous effects of STCs across firms, we interact (lagged) firm size with the STC dummy. This is a crucial test to determine how different firms react to the introduction of new restrictive SPSs. In addition, for a more comprehensive view of the heterogeneous effects across firms, we introduce two other proxy variables for firm size. The first accounts for firms' market share in the destination market, assuming that firms with higher export share are larger. It is computed as the ratio between total firm exports in a given productdestination market, over the total export in the same product-destination market. The second proxy accounts for firms' multi-destination status, based on the fact that the number of served markets is positively correlated with firm productivity and size (Bernard, Redding, and Schott 2011). Multi-destination status of a firm is captured by a dummy variable that identifies the top $10 \%$ exporting firms in terms of number of destination markets served. ${ }^{18}$

The specification also controls for bilateral import tariffs. According to Orefice (2017) and Beverelli, Boffa and Keck (2014), there is a positive association between countries' tariff reduction and the maintenance of trade-restrictive SPS measures that are subject to STCs, which in turn leads one or more countries to raise a STC on these measures. ${ }^{19}$

\section{Identification issues}

Equation (1) may suffer from standard endogeneity problems due to selection and omitted variables bias, measurement errors and reverse causality. However, it is worth noting that all our empirical estimations include firm-level and destination-product-time fixed effects. In this way, we identify the STCs effect by exploiting the within-firm variation in the

\footnotetext{
${ }^{17}$ The choice to proxy firm size in terms of productivity with firms' total trade is due to the lack of balance sheet information in the Peruvian customs database.

${ }^{18}$ Note that in computing the number of market served by the firms, we only consider STCs-free market-product destinations. The threshold which defines the multi-destination status of a firm in our sample is 10 destination markets. Firms exporting in 10 or more markets in the first year of the analysis are then considered multidestination firms.

${ }^{19}$ The correlation between the STC and tariff variables in our sample is strongly negative and significant. This test, even with some caveats linked to endogeneity issues, seems to confirm in our sample what was previously stated by Orefice (2017) and Beverelli, Boffa and Keck (2014).
} 
outcome of interest, after controlling for every destination-product-time specific idiosyncratic factors, such as demand and supply shocks. From this perspective, our specification allows little room for selection and omitted variable bias, and it is close to a difference-in-difference research design.

More problematic could be, in principle, endogeneity due to measurement errors and simultaneity bias. However, as we discuss below, these problems may induce, if anything, only attenuation bias in our estimations. This in turn suggests that the results reported below should be interpreted as a lower bound of the actual STCs effect. To better motivate this statement, it is useful to be more precise about the nature of our key variable of interest (i.e. STCs).

Specific trade concerns are not direct measures of SPS stringency. Clearly, to rise an STC, some exporting countries must be sufficiently unhappy about a given importing country's practice, and this could happen under different situations: because (1) importing countries introduced a new written standard or strengthened an existing written standard; (2) importing countries started implementing more stringent enforcement of an existing standard without changing the written standard; (3) exporting countries such as Peru (or countries similar to Peru) are increasing or decreasing exports and found the existing standard cumbersome to comply with, without any change of written standard or implementation of it. Ideally, situations like (1) and (2) are the ones we want to exploit for identification. Differently, a situation like (3) would be problematic because they can be the result of a reverse causality problem. So we need to be sure that in our data these situations are ruled out.

It is worth noting that we do not consider bilateral STCs in our analysis (i.e., STCs raised by Peru). This means that we only consider the information on country imposing the SPS measure on a given product, but we do not use the information on countries that deem that measure to be trade restrictive and that, thus, raise the concern. Therefore, it is very unlikely 
that countries maintaining a restrictive trade measure would consider (more visible) Peruvian firms as their main target. In addition, Peru has only very rarely raised an issue against any country (i.e., only three cases during the period of analysis), nor has been identified as a main country imposing SPS measures. This apparently non-active role of Peru in the WTO SPS committee is consistent with the observation that relatively few issues are raised by small and developing countries, likely because of high political and opportunity costs (Fontagné et al. 2015). In our work, we assume that, due to the non-discrimination rule of the WTO, once a measure is considered trade restrictive for a WTO member, this holds true for all other WTO members and particularly for developing countries. ${ }^{20}$

However, one can argue that the few STCs raised directly by Peru, are the consequence of situations where similar countries, such as other Latin American countries, just anticipated Peru in the SPS Committee. If this is the case, then all the STCs raised by similar countries could potentially represent a source of simultaneity bias if the underlying motivation follows a situation like (3). However, from the text of the STC it is only rarely possible to discern with a sufficient degree of certainty the real motivation inducing a country to rise a STC. For this reason, as a robustness check, we also run our main estimations by dropping all the STCs raised by Latin American countries. If the results prove to hold to this test, this will provide further credence to our identification strategy.

In addition, to address potential endogeneity concerns directly we also rely on an instrumental variable (IV) approach proposed by Fontagné and Orefice (2018). As better discussed in supplementary information (Section B), we used as instrument a dummy variable

\footnotetext{
${ }^{20} \mathrm{We}$ are aware that some STCs apply almost exclusively on a bilateral base, as they are raised on countryproduct specific assessment. However, most of the STCs refers to measures (especially imposed by developed countries), whose trade restrictiveness is shared by almost all the countries aimed at exporting there. A meaningful example is given by the high restrictiveness of European Union countries on the Maximum Residue Limit (MRL) allowed on the imported products. Notwithstanding, almost 50\% of the STCs raised toward the EU concern this issue, that involved in particular fruit and vegetable products which are by far the most exported products by Peruvian firms. However, no STCs have been raised by Peru toward the EU on this issue over the whole period. Despite this fact, it is hard to argue that Peruvian exporters are not affected by the high stringency imposed by the EU on the imported agri-food products.
} 
(and its interaction with size), which takes the value of one if the following two conditions hold (and zero otherwise). The underlying idea is that the probability to have an active SPS STC for a country $j$ on a given product $h$, is, first, positively associated with the propensity of that country to impose measures that are considered trade restrictive by other countries in products other than $h$; second, with the sensitivity of that product to be the target of strict SPS measures (in countries other than $j$ ) that are then considered as trade protectionist. Here, the imposition in country $j$ of strict SPS measures in product other than $h$, and the enforcement of SPS measures that will be then the target of STCs in countries other than $j$ on the same product $h$, are presumably be exogenous to a STC that is raided on product $h$ in country $j$, ceteris paribus.

As discussed in the data section, a final concern about STCs data is related to their timing, namely that STCs may sometimes refer to measures that are likely to act as a trade hurdle years before the concern is raised, inducing an error-in-variable problem. From this perspective, it is important to keep in mind that, as an effect of the many fixed effects included in our equation (1), measurement error in a right-hand side variable, if any, will induce attenuation bias in our estimated effect (Wooldridge, 2010).

A final note is given on the choice of the linear probability model, that is used irrespective of the binary nature of some of the outcome variables (i.e., extensive trade margin and exit variable). Given the multitude of fixed effects in the specifications, non-linear estimation procedures, such as logit or probit, suffer from the well-known incidental parameter problem. For comparability purposes, the standard OLS estimator is thus preferred throughout all model specifications. 


\section{Results and Discussion}

\section{Effect of Standards on Trade Margins and Exit Rate}

The estimated impacts of STCs on the extensive margin are reported in Table 2 (columns 1-3). Results in column 1 show that STCs negatively affect the probability that a firm exports to a product-destination country maintaining a restrictive SPS measure. The estimated coefficient is significant at $1 \%$ level, and is robust across different specifications. The magnitude of the estimated effect suggests that the presence of a new STC reduces the probability to export by about $5.5 \%$, on average, representing a relevant economic effect. Note also that the tariff coefficient is negative and strongly significant.

Estimated effects for firm-level covariates indicate that the probability of firms exporting in a given destination is significantly higher for larger firms, irrespective of the type of firm size proxy used in the regressions. The estimated coefficient for the interaction term between firm-level size and STCs is positive and significant, for all the size variables considered. ${ }^{21}$ Overall, these results suggest that larger firms are less affected by STCs. Put differently, a new stringent SPS measure induces a selection effect that discriminates against small and less efficient firms, because it raises fixed and variable trade costs $-\mathrm{a}$ result consistent with Melitz-Cheney type firm-heterogeneity trade models.

Columns 4-6 (Table 2) report the STC effect on the probability of firms ceasing to export a given product to a given destination (exit). Overall, the results strongly confirm the findings on the extensive margin. A new restrictive SPS measure, by increasing the fixed costs of trading to a certain product-destination, induces firms to exit from that export market. This finding is consistent with other recent studies on TBT-STCs (Fontagné and Orefice 2018) and SPS-STCs (Fontagné et al. 2015). The impact of a new STC on the exit probability

\footnotetext{
${ }^{21}$ It is important to note that we run all our estimations also excluding firm fixed effects, and so exploring not only the within-firm but also between-firm variation over time. The heterogeneous effects of STCs on firms' size remain stable over all estimations.
} 
decreases with firm size. As in the case of the extensive margin, the results hold when using market share and multi-destination size variables as the firm-size proxy, while in the total export case the result is opposite, although the effect is non-significant. Overall, the negative effect of restrictive SPS affected by STCs on the extensive margin of trade, and their heterogeneity across firms of different size, mimic similar findings reported in Fontagné et al (2015) on French manufacturing firms, and are also similar to those of Fernandez et al. (2017) who considered developing country exports.

The results of regressions on export values are reported in columns 7-9 of Table 2. The STCs reduce firms' export values, with estimated effects consistent across different specifications and significant at $1 \%$ level. Conditional on exporting, considering the average estimated effects in columns $7-9$, the export value of firms reduces by about $65 \%$ in productdestinations affected by STCs, making this a large economic effect. To make a comparison with the estimated negative trade effect induced by tariffs, an increase in tariffs of $10 \%$ reduces export values by "only" $21 \%$. It is possible to translate the quantity effect of STCs into their ad valorem equivalent (AVE) tariff using the estimated elasticity of substitution, i.e., the coefficient on the tariff term. ${ }^{22}$ The resulting AVE of STCs is between $39-50 \%$, depending on the specification, a result fully consistent with recent evidence by Ning and Grant (2019). ${ }^{23}$ Finally, for the heterogeneous effects across firms for the intensive margin, smaller firms appear again to pay higher costs when a strict standard is imposed in a given product-destination market. This result holds for all the different measures of firm size.

Overall, these findings are consistent with, but considerably larger than, those found for French manufacturing firms by Fontagné et al. (2015). However, the negative effect of

\footnotetext{
${ }^{22}$ Under standard gravity with Constant Elasticity of Substitution (CES) preferences, conditional to exporting, the estimated quantity effect of the STC coefficient $\left(\beta_{1}\right)$ can be converted into the correspondent $\operatorname{AVE}=\left[\exp \left(\beta_{1}\right)\right.$ $-1] / \sigma$, where $\sigma$ is the firm-level estimate of the elasticity of substitution (i.e., the estimated coefficient on the tariffs, equal to about 2.1 in absolute value, considering the average estimated tariff effects in columns 7-9).

${ }^{23}$ Ning and Grant (2019), showed that the ad-valorem equivalent imposed by SPS trade concern measures ranges from $33 \%$ to $106 \%$ equivalent tariff, on average.
} 
restrictive SPSs on firms' export value is different from some previously published papers (see, e.g., Ferro et al. 2015), and in particular with the findings in Fernandez et al. (2017) who, instead, conditional on trade, do not find any significant (negative) effect of stringent MRL on firms' export volume. The more logical interpretation behind these different findings lies in the nature of food standards considered: MRL standards in Fernandez et al. (2017) versus restrictive SPS targeted by STC in the present paper. $^{24}$

To elucidate the heterogeneous effects of SPS STC with respect to firms' size, we plot in Figure 3 their marginal effects considering the different trade outcomes analyzed in this section. ${ }^{25}$ The results clearly show that both extensive and intensive margins increase with firms' size, while the marginal effects on firms' exit probability show an opposite pattern. When looking at the results on the extensive margin, it is interesting to note that in the noSTCs scenario, smaller firms have a higher extensive margin than in the STC one. However, this result reverses when considering larger firms. A similar pattern emerges in the intensive margin case, although the results do not show an intersection of the no-STC and STC lines, which anyway converge moving from smaller to larger firms. When considering firms' exit, the results show a much higher probability to exit from the market where STCs are present than in markets with no-STCs. It is interesting to note that while the no-STC line is quite flat, thus showing only marginal differences in the exit rate conditional on size, the STC line declines considerably moving from smaller to larger firms.

Taken together, the results of these graphs clearly show that smaller firms more than larger ones incur in net losses in presence of STCs, compared to a no-STC scenario. However, it is worth highlighting that when considering export probability, larger firms show a net gain in presence of STCs in comparison to a no-STC scenario.

\footnotetext{
${ }^{24}$ In fact, though MRL standards are just a specific type of SPSs, it is worth noting that considering the overall SPSs affected by STCs, the share of MRLs is lower than 15\%. This share rises only when STCs against EU SPSs are considered.

${ }^{25}$ Note that the marginal effects have been computed considering the results obtained using market share as a size variable, and, thus, the results obtained in columns 2,5 and 8 , of Table 2 .
} 
Results in Table 3 consider separately all other NTMs not affected by STCs, namely by distinguishing between SPS, TBT and border NTMs. The results in column 1 suggest that SPS, and less so TBT, positively affect firms' extensive trade margins, while border NTMs prove to exert an opposite effect, with the negative effect of STCs that remains robust and significant and even increases in magnitude. When further distinguishing between regular and emergency SPSs (column 2), the estimated effect is positive for the former but negative for the latter, a result fully consistent with common intuition. The effect of other NTMs in inducing firms' exit from markets where they are applied (columns 3 and 4) suggests a positive and significant effect of TBT and SPS emergency measures, while the regular SPS and border NTM prove to have no impact on firms' exit. When considering the effect of the other NTMs on the intensive margin (column 5 and 6), the results are in line with those obtained for the probability to export, suggesting a positive and significant effect for SPS (in particular regular) and TBT measures, while the opposite holds for border NTMs. Thus, our results suggest that when the effect of most restrictive SPS standards affected by STC are controlled for, SPS measures (in particular regular SPS), and TBTs, act as trade enhancing measures, increasing both the probability of firms' export and the value of firms' exports.

Overall, the above results give an idea of the complexity of disentangling the NTMs effects on different margins of adjustment, and underscore the usefulness of a comprehensive treatment of NTMs. The results clearly show that accounting for the stringency of most restrictive SPS measures that are subject to STC, not surprisingly, matters for the interpretation of final results. Hence, the idea that one-size-fits-all does not work with agrifood standards.

As discussed in the identification strategy section, our empirical specifications may suffer from endogeneity bias for different reasons. In order to rule out reverse causality issues, we run our main specifications, first, by omitting in our STC variable all the STCs raised by 
other Latin American countries; second, using our instrumental variable approach, where our instrument for the SPS STC (as explained in Additional material section) is a dummy that enters in our estimation both linearly and interacted with the size variable. The results of these tests are shown, respectively, in Table A3 and Table A4 of the Additional materials section. The main findings still hold to these important robustness checks. Moreover, concerning the IV estimations, the joint F-test computed on the first stages suggests that our instruments are relevant, so that the first stage is consistently identified.

\section{Effect of Standards on Prices, Quality and Quality-Adjusted Prices}

One of the most innovative contributions of the present work is the analysis of the effect of STCs (and other NTMs) on the firm-level export price, product quality and qualityadjusted price. Table 4 reports regression results for this analysis. In particular, results consider both firm-level (log)prices and (log)quality-the last measured following the Khandelwal, Schott and Wei (2013) approach. Furthermore, because the quality-adjusted price is the $(\log )$ difference between firm-level price and quality, that is $\ln \hat{p}_{-} a d j_{-} \xi=$ $\ln p-\ln \hat{\xi}$ (see Appendix A for details), the estimated difference in the effects of STCs and other NTMs between the price and the quality regression coefficients, by construction, is attributable to the pure pricing strategy of the firm. ${ }^{26}$

As expected, STCs and all other NTMs but border NTMs and emergency SPSs, induce a statistically significant increase in firm-level export prices, conditional on exporting. ${ }^{27}$ The

\footnotetext{
${ }^{26}$ Note therefore that, by construction, the estimated effect on price is the sum of its quality and quality-adjusted price coefficients. Thus, our estimations allow computing to what extent the estimated effect of STCs and NTMs on price is attributable to the quality and quality-adjusted price components.

${ }^{27}$ Note that although quality and price are measured at the same level of aggregation than the intensive margin (i.e. HS 10-digit level), the number of observation in these estimations is lower than that in the estimations of the extensive margins. This is due to several reasons: first, quality has been estimated using elasticity of substitutions at the destination country-product (HS 3-digit) level using data from Broda et al. (2006). Therefore, where data are missing, quality could not be estimated. Second, we use a quite common standard data cleaning approach in the quality estimation, following Khandelwal (2010) and Colantone and Crinò (2014) among others, by trimming observations with extreme unit values and unit values yearly growth falling above and below the $99^{\text {th }}$ and $1^{\text {st }}$ percentile of the sample distributions, respectively. In addition, since quality estimations are notoriously noisy, we dropped estimated quality following above and below the $95^{\text {th }}$ and $5^{\text {th }}$ percentile.
} 
magnitude of the effect is higher for STCs, followed by TBTs and SPSs, respectively. This result confirms the findings of Fontagnè et al. (2015) on the positive price effect of STCs, but again contrasts the results of Fernandez et al. (2017) who did not find any significant effect of MRLs on firm export unit values. The increase of export prices, conditional on exporting, suggests that for Peruvian firms STCs and other NTMs impose both fixed and variable costs. However, only for the most restrictive SPS affected by STCs the increase in price is largely explained by a rise in the quality of exported products. Indeed, the effect of STCs on prices is more than $95 \%(0.321 / 0.331)$ attributable to quality upgrading, while quality-adjusted price is unaffected. ${ }^{28}$ Conversely, the rise in export prices induced by regular SPSs and TBTs, does not significantly affect product quality, but significantly increase quality-adjusted prices. Thus, once again, there is clear evidence that standards with different stringency induce differentiated effects on firms' export decisions.

Looking at the data it is difficult to understand what mechanisms are driving the effect of STCs on firms' pricing and quality strategy. Indeed, although Peru is a prominent exporter, especially for some products, it is not a price setter in all markets. From this perspective, the estimated changes in prices under STCs are somehow surprising. An interpretation of this result may be that STCs affect the quality of the exported products and, as a result, then the market adjusts the price. This is because the STC clears out less competitive and lower quality suppliers as shown above, and so the average quality increases with fewer suppliers. As a results, final prices increase..$^{29}$

Considering the heterogeneous effect conditional on size, it is worth noting that export prices are positively associated with firms' size, although the effect is not statistically significant (columns 1-3). The coefficients on firms' size suggest opposite relationships with quality and quality-adjusted price. While, as expected, product quality is positively associated

\footnotetext{
${ }^{28}$ Note that this simple computation considers estimated coefficients for Dummy STC in Table 4, column 1 and 4 , and refer to the effect of STCs on price and quality, respectively.

${ }^{29} \mathrm{We}$ thank an anonymous referee for suggesting this potential interpretation of the results.
} 
with firms' size, the opposite holds for the quality-adjusted price component. These coefficients however do not imply that larger firms export higher quality products at lower price. The price decomposition suggests that export quality increases with size but this occurs without a significant change in export price. This no-price effect is explained by the negative coefficient of the quality-adjusted price component. In practice, the higher quality products provided by larger firms do not lead to a full adjustment in their relative prices, as a sort of incomplete pass-through of quality to export price.

Importantly, the interaction between firm size and STCs is negative and significant in both the price and quality regressions (see columns 1-3 and 4-6, respectively), but approaches zero and is non-significant for the quality-adjusted price component (columns 79). These additional results suggest that the positive effects of STCs on prices and quality are less strong for larger firms. Figure 4, gives a graphical representation of marginal effects of the presence of an active STC in the product-destination market conditional on firms' size, considering respectively price, quality and quality-adjusted price. These graphs suggest that in absence of restrictive SPS measures, firms export at lower price and lower quality with respect to markets where active SPS STCs are present. When looking at the marginal effects in the quality-adjusted price case, we cannot appreciate any significant difference of the size effect conditional on STC. It is worth noting that the evolution of the STC and no-STC lines in the cases of price and quality is different. In the former case, in absence of STCs export prices increase slightly with firms' size, while the opposite holds in presence of STCs, meaning that the adjustment to the STC requirements forces smaller firms to increase their price more than larger firms. When considering quality, both the STC and no-STC lines are increasing with firms' size. However, in presence of STC the line is more flat, suggesting that smaller firms have to adapt more their quality to the new requirements than larger firms. 
Finally, and in accordance with the evidence in Asprilla et al. (2019), exporters facing higher tariffs in the destination markets adopt pricing to market strategies, by setting lower export prices when tariffs increase, thus revealing a loss of market power consistent with rentshifting effects. Indeed, tariffs induce firms to export higher quality products but at a significantly lower quality-adjusted price. In comparison, the effect of restrictive SPSs on price and quality is significantly different.

Also for this set of estimations, we address potential endogeneity concerns by following the strategy explained in the Identification section and also adopted with trade margins and exit probability. The results of these tests considering price, quality and quality-adjusted price as outcome variables are shown in Table A3 and Table A4 of the Additional materials section, respectively. Importantly, as can be clearly seen from the reported figures, the main results prove to hold to these additional robustness checks.

In addition, we also run a Three-Stage Least Squares model to control for the likely correlation of our price and quality measures. The results of this test are presented in Table A7 of the Supporting Information section. We employ this methodology considering both STCs as exogenous (column 1 and 2) and endogenous variables (columns 3 and 4). In the latter case, we use the same instruments discussed in our Identification section and employed in regressions in Table A.4. The results go in the expected direction, with the estimated coefficients that remain almost unaffected, while their standard errors reduce with respect to the simple OLS and 2SLS estimations.

\section{Heterogeneous Effects for Product Differentiation}

The introduction of a restrictive SPS measure, other than inducing a market share reallocation from small (and low-quality) to large (and high quality) firms, may limit the range in which firms can differentiate their products, thus making competition tougher. To understand better if the last mechanism is driving our results, we now test whether the effects 
on firms' quality and pricing behavior are heterogeneous across products with different scope for quality differentiation. To this purpose, we use the concept of quality ladder, as a proxy for the level of product differentiation (see Khandelwal 2010). Quality ladder is computed as the difference between the maximum and minimum values of estimated quality in a given product-destination category. In particular, products with a value of quality ladder below the median (short-quality ladder) are characterized by lower product differentiation, hence, horizontal differentiation prevails. In contrast, products displaying a value of quality ladder above the median (long-quality ladder) are more differentiated and, thus, vertical differentiation prevails. This additional test should better clarify if most restrictive SPSs act differently on firm pricing and quality strategy when considering products where horizontal or vertical differentiation prevails. ${ }^{30}$

Table 5 presents the results considering products-destinations characterized by a shortquality ladder, and a long-quality ladder. ${ }^{31}$ To this purpose, we interact a short- and a longquality ladder dummy variable in the full sample with our main control variables of interest.

When considering the results for price (columns 1 and 2), STCs and all the other NTMs, with the exception of border NTMs in short-quality ladder, lead to an increase of Peruvian firms' export prices. Considering in particular STCs, this effect proved to be higher in magnitude in the short-quality ladder than in the long-quality ladder case. Results on quality (columns 3 and 4) suggest that STCs have a positive effect in both type of markets, with a magnitude that is higher in the long-quality ladder than in the short-quality ladder case. Other NTMs have a weaker effect on quality, with border NTMs presenting a positive effect on quality in the short-quality ladder case, while the opposite holds in the long-quality ladder

\footnotetext{
${ }^{30}$ Note that, as most restrictive SPS measures that are subject to STCs could clearly induce changes in the level of quality differentiation, our measure of quality ladder is computed in the first year of the observed period.

${ }^{31}$ For Peruvian agricultural exports, fruit and vegetable products are important in the long quality ladder, and meat and dairy products in the short quality ladder. Products for which Peru has a comparative advantage are mostly vertically differentiated, but products for which Peru is less competitive are more horizontally differentiated.
} 
one. SPS measures do not show any significant effect, while TBT present a negative effect in the long-quality ladder case. Finally, considering STCs and all the other NTMs, the results on quality-adjusted price (columns 5 and 6 ) are in line with those of price, with the exception of STCs. The results indeed suggest a significant negative effect of STCs on quality-adjusted price in the long-quality ladder case, while the effect in the short-quality ladder one remains positive and (barely) significant.

Overall, these results suggest that for short-quality ladder product-destinations, STCs have a positive effect on price, which is the results of a similar increase in both the quality and quality-adjusted price components. Conversely, considering the long-quality ladder case, more restrictive SPSs affected by STCs induce an increase in firms' export prices, which is overcompensated by a process of quality upgrading, with a contemporaneous reduction of the quality-adjusted price component.

However, when looking at the estimated effect of $(\log )$ size interacted with the STC dummy, the results suggest that both in the short- and long-quality ladder cases, the positive effect of STCs on price and quality are stronger for smaller than for larger firms. STCs appear not to affect significantly firms' quality adjusted price conditional on size in the short-quality ladder case. Conversely, in the long-quality ladder case larger firms increase more their quality-adjusted price than smaller ones in presence of SPS that are subject to a STC.

In summary, when considering products with different scope for quality differentiation, our analysis provides new insights. The effect of stricter SPSs is quite heterogeneous in affecting firms' pricing and quality behavior. While neither quality nor quality-adjusted price components seems to prevail for products where price competition dominates, conversely the quality effects highly prevail for products where quality competition dominates. These results appear consistent with economic expectations, which raises the credence and reliability of the quality measure used in this analysis. 


\section{Conclusion and policy implications}

In this paper we examine how NTMs in general, and the most stringent SPSs that are subject to STCs in particular, affect firm-level trade margins, price and product quality for agri-food export firms in Peru. This is an interesting case study because Peru experienced an impressive growth in agri-food exports, precisely in sectors most affected by NTMs. In addition, in Peru, like elsewhere, there are relatively few documented instances in which large numbers of small-scale producers have successfully integrated into high-value niche markets. As clearly documented in the present paper, this lack of success may be attributed, at least partially, to the fact that some non-tariff measures are too demanding to allow them to enter these markets.

Indeed, we find that the most restrictive standards for which STCs are raised have a strong trade-reducing effect for Peruvian firms, by affecting both the extensive and intensive margin of trade, as well as the exit probability, an effect particularly strong for smaller firms. In contrast, SPS (in particular regular SPS) and TBT show a positive effect on the extensive and intensive margin of trade, while TBT measures increase the probability of firms' exit. Effects are important in economic terms, in particular for STCs. The presence of a new STC in a given country-product line proved to decrease firms' export probability and their export value by about $5 \%$ and $65 \%$, respectively, and to increase firms' exit rate by about $5 \%$. These trade-reducing effects are especially strong for small and medium firms. However, and interestingly, for a small group of very large firms, these effects can even reverse.

We find that only the most stringent standards, for which STCs were raised, lead to quality upgrading. This effect is more pronounced for smaller firms and mostly evident in vertically differentiated products. Conversely, a pure price increase is only identified for horizontally differentiated products, though less so for large firms. Other standards, including SPS, TBT and border NTMs, do not result in quality upgrading but lead to higher export 
prices. The findings that the most stringent standards induce (especially smaller) firms to exit export markets and at the same time lead to quality upgrading in surviving firms, corroborate recent empirical evidence showing that quality of exported products is one of the main determinants of firms' success in export markets (Verhoogen 2008; Khandelwal 2010).

Finally, our result support the notion that exporters facing higher tariffs in the destination markets adopt pricing to market strategies, by setting lower prices when tariffs increase, revealing a loss of market power consistent with rent-shifting effects. These results are clearly contrasting with those on STCs and NTMs, suggesting important differences in the way they may alter competition and market structure.

The results emerging from this paper may have some relevant implications. First, and perhaps more importantly, results clearly suggest that most restrictive SPSs that are subject to STCs, by discriminating against smaller firms, lead to a more concentrated export markets, where larger firms further increase their market share. This evidence could be particularly critical in a developing country like Peru, where small firms represent the large majority. An increase of restrictive standards could indeed raise inequality, also in terms of wage and poverty, as these firms absorb the large majority of unskilled workers.

A second potential implication of our findings is related to the different effects on firms' export price and quality exerted by NTMs characterized by different restrictiveness. While for the most restrictive SPSs targeted by STCs the increase in export prices is fully absorbed by products' quality upgrading, this is not the case for the majority of regular SPSs and TBTs. In the latter cases, the increase in export price is fully explained by an increase in qualityadjusted prices, while product quality of the surviving firms results unaffected. This result is somehow puzzling, as it suggests that several food safety and quality standards imposed in particular by more advanced economies, actually do not bring extra benefits to consumers. In contrast, these standards seem apparently to increase the market power of surviving firms. 
Because worldwide we are experiencing a reduction of tariffs, that are partially substituted with NTMs, it should be of relevant importance in bilateral and multilateral trade negotiations to put more emphasis on specific provision for NTMs, considering not only their trade effect, but focusing also on their (possible) anti-competitive effect.

Third, our results clearly support the promotion of policies focused on facilitate exports of smaller firms, for which the barriers associated with increasing standards in international markets are more challenging but for which the benefits (conditional on remaining in the market) could be also higher. From this perspective, it is of relevant importance for developing countries to raise their voices in global and bilateral trade fora, and increase their capacity to negotiate favorable conditions in trade agreements, to reach fairer global competition.

Clearly, all the above findings (and implications) are the result of a case-study that focused on Peruvian exporting firms. As such, while we are confident that the above results, on average, have similar implications for many other developing countries, we are still far from a full comprehension of the complex role played by (different) NTMs. However, by working with the entire portfolio of NTMs, our analysis allows assessing the different trade and quality effect of standards with different stringency. From this perspective, this approach looks promising for a better understanding of the complex impact of NTMs. We believe this is an important message of our paper, because, as recently argue by Ning and Grant (2019), the use of a broad based approach attempting to quantify the trade effect of thousands of NTMs may lead to ambiguous trade outcomes. This calls for further similar investigations exploiting firm-level data in other developing countries. 


\section{References}

Abel-Koch, J. 2013. Endogenous Trade Policy with Heterogeneous Firms. Working Papers 1306, Gutenberg School of Management and Economics, Johannes Gutenberg-Universität Mainz.

Amiti, M., and Khandelwal, A. 2013. Import Competition and Quality Upgrading. The Review of Economics and Statistics 95 (2): 476-90.

Arita, S., Beckman, J. and Mitchell, L. 2017. Reducing Transatlantic Barriers on US-EU Agri-food Trade: What are the Possible Gains? Food Policy, Vol. 68: 233-247.

Arkolakis, C. 2010. Market Penetration Costs and the New Consumers Margin in International Trade. Journal of Political Economy 118 (6): 1151-99.

Asprilla, A., Berman, N., Cadot, O. and Jaud, M. 2019. Trade Policy and Market Power: Firm-level Evidence. International Economic Review. https://doi.org/10.1111/iere.12409

Baldwin, R.E. 2000. Regulatory Protectionism, Developing Nations and a Two-Tier World Trading System. In Collins, S. and D. Rodrik (Eds), Brookings Trade Forum. Washington DC: Brookings Institution Press, 237-93.

Beghin, J.C., Maertens, M. and Swinnen, J. 2015. Non-tariff Measures and Standards in Trade and Global Value Chains. Annual Review of Resource Economics 7 (1): 425-50.

Bellone, F. Musso, P. Nesta, L. Warzynski, F. 2016. International trade and firm-level markups when location and quality matter. Journal of Economic Geography 16(1): 67-91.

Bernard, A.B.. Redding, S.J and Schott, P.K. 2011. Multiproduct Firms and Trade Liberalization. The Quarterly Journal of Economics 126 (3): 1271-1318.

Bernard, A.B., Redding, S.J. and Schott, P.K. 2012. The Empirics of Firm Heterogeneity and International Trade. Annual Review of Economics 4: 283-313. 
Beverelli, C., Boffa, M. and Keck, A. 2014. Trade Policy Substitution: Theory and Evidence from Specific Trade Concerns. WTO Staff Working Papers ERSD-2014-18.

Broda, C., Greenfield, J. and Weinstein, D. 2006. Globalization and the Gains from Variety. NBER Working Paper 12512.

Brooks, E.L. 2006. Why Don’t Firms Export More? Product Quality and Colombian Plants. Journal of Development Economics 80: 160-78.

Cadot, O., Gourdon, J. and van Tongeren, F. 2018. Estimating Ad Valorem Equivalents of Non-Tariff Measures: Combining Price-Based and Quantity-Based Approaches", OECD Trade Policy Papers, No. 215, OECD Publishing, Paris.

Caswell, J. and Mojduszka, E.M. 1996. Using Informational Labeling to Influence the Market for Quality in Food Products. American Journal of Agricultural Economics 78(5): 1248-1253.

Chaney, T. 2008. Distorted Gravity: The Intensive and Extensive Margins of International Trade. American Economic Review 98 (4): 1707-21.

Chen, M., Wilson, J. and Otsuki, T. 2008. Standards and Export decisions: Firm-level Evidence from Developing Countries. The Journal of International Trade \& Economic Development 17 (4): 50123.

Colantone, I. and Crinò, R. 2014. New imported inputs, new domestic products. Journal of International Economics 92 (1), 147-165.

Crozet, M., Head, K. and Mayer, T. 2012. Quality Sorting and Trade: Firm-level Evidence for French Wine. Review of Economic Studies 79 (2): 609-44.

Curzi, D. and Olper, A. 2012. Export Behavior of Italian Food Firms: Does Product Quality Matter? Food Policy 37 (5): 493-503.

Curzi, D. and Pacca, L. 2015. Price, Quality and Trade Costs In The Food Sector. Food Policy 55: $147-58$. 
Curzi, D., Raimondi, V. and Olper, A. 2015. Quality Upgrading, Competition and Trade Policy: Evidence from the Agri-Food Sector. European Review of Agricultural Economics 42(2): 239267.

Dal Bianco, A., Boatto, V.L., Caracciolo, F. and Santeramo, F.G. 2016. Tariffs and non-tariff frictions in the world wine trade. European Review of Agricultural Economics 43(1): 31-57.

Disdier, A.C. and Marette, S. 2010. The combination of gravity and welfare approaches for evaluating non-tariff measures, American Journal of Agricultural Economics 92(3): 713-726.

Disdier, A.-C., Fontagné, L. and Mimouni, M. 2008. The Impact of Regulations on Agricultural Trade: Evidence from the SPS and TBT Agreements. American Journal of Agricultural Economics 90(2): 336-50.

Food and Agriculture Organization (FAO). 2011. Cost-effective management tools for ensuring food quality and safety. FAO training materials for agricultural management, marketing and finance. FAO, Rome.

Feenstra, R. C. and Romalis, J. 2014. International prices and endogenous quality. The Quarterly Journal of Economics 129: 477-527.

Fernandes, A.M., Ferro, E. and Wilson, J. 2019. Product Standards and Firms' Export Decision. The World Bank Economic Review 33( 2): 353-374.

Ferro, E., Wilson, J. and Otsuki, T. 2015. The Effect of Product Standards on Agricultural Exports. Food Policy 50: 68-79.

Fontagné, L., and Orefice, G. 2018. Let's Try Next Door: Technical Barriers to Trade and MultiDestination Firms. European Economic Review 101: 643-663.

Fontagné, L., Orefice, G., Piermartini, R. and Rocha, N. 2015. Product Standards and Margins of Trade: Firm-level Evidence. Journal of International Economics 97: 29-44.

Freund, C., and Pierola, M.D. 2010. Export Entrepreneurs: Evidence from Peru. Policy Research Working Paper Series 5407. Washington DC: The World Bank. 
Gagné, C. and Larue, B. 2016. Public quality standards and the food industrys structure in a global economy. Review of Agricultural, Food and Environmental Studies 97: 141-148.

Grant, J. H. and Arita, S. 2017. Sanitary and Phytosanitary Measures: Assessment, Measurement, and Impact. Commissioned Paper No. 21, International Agricultural Trade Research Consortium (IATRC)

Grunert, K.G. 2005. Food quality and safety: consumer perception and demand. European Review of Agricultural Economics 32(3): 369-391.

Hallak, J.C. and Sivadasan, J. 2013. Product and Process Productivity: Implications for Quality Choice and Conditional Exporter Premia. Journal of International Economics 91 (1): 53-67.

Henson, S. and Reardon, T. (2005). Private agri-food standards: Implications for food policy and the agri-food system. Food Policy 30(3): 241-253.

Hu, C. and Lin, F. 2016. Product Standards and Export Quality: Micro Evidence from China. Economics Letters 145: 274-7

IFAD 2017. Food safety, trade, standards and the integration of smallholders into value chains. A review of the literature. IFAD Research Series 11.

ITC 2012. Peru: Company Perspectives - An ITC Series on Non-Tariff Measures. Technical Paper Doc. No. MAR-12-221.E. Geneva: ITC.

Jaffee, S. and Henson, S. 2005. Agro-Food Exports from Developing Countries: The Challenges Posed by Standards. In Aksoy, A.M., and J.C. Beghin (Eds.), Global Agricultural Trade and Developing Countries. Washington DC: The World Bank.

Khandelwal, A. 2010. The Long and Short of Quality Ladders. Review of Economic Studies 77 (4): $1450-76$.

Khandelwal, A.K., Schott, P.K. and Wei, S.J. 2013. Trade Liberalization and Embedded Institutional Reform: Evidence from Chinese Exporters. American Economic Review 103 (6): 2169-95. 
Krugman, P., 1980. Scale Economies, Product Differentiation, and the Pattern of Trade, American Economic Review 70, 950-59.

Kugler, M. and Verhoogen, E. 2012. Prices, Plant Size, and Product Quality. Review of Economic Studies 79, 307-39.

Leland, H. E. 1979. Quacks, Lemons, and Licensing: A Theory of Minimum Quality Standards, Journal of Political Economy, 87, 1328-1346.

Maertens, M. and Swinnen, J. 2009. Trade, Standards, and Poverty: Evidence from Senegal. World Development 37 (1): 161-78.

Manova, K. and Yu, Z. 2017. Multi-Product Firms and Product Quality. Journal of International Economics 109 (C): 116-37.

Mayer, T., and Ottaviano, G. 2008. The Happy Few: The Internationalisation of European Firms. New Facts Based on Firm-Level Evidence. Intereconomics 43(3): 135-148.

Melitz, M., and Ottaviano, G. 2008. Market Size, Trade and Productivity. Review of Economic Studies 75: $295-316$.

Melitz, M. 2003. The Impact of Trade on Intra-Industry Reallocations and Aggregate Industry Productivity. Econometrica 71 (6): 1695-725.

Murina, M. and Nicita, A. 2017. Trading with Conditions: The Effect of Sanitary and Phytosanitary Measures on the Agricultural Exports from Low-income Countries. The World Economy, 40(1) $168-181$.

Navdi, K. 2008. Global standards, global governance and the organization of global value chains. Journal of Economic Geography 8 (3): 323-343.

Ning, X. and Grant, J. 2019. New Estimates on the Ad-Valorem Equivalents of SPS Measures: Evidence from Specific Trade Concerns. Research Report CAT-2019-10.

O’Brien, T. and A. Diaz Rodriguez. 2004. Improving competitiveness and market access for agricultural exports through the development and application of food safety and quality standards. 
The example of Peruvian asparagus. Report by the Agricultural Health and Food Safety Program of the Inter-American Institute for Cooperation on Agriculture. Coronado, Costa Rica.

Olper, A. (2016). The political economy of trade-related regulatory policy: environment and global value chain. Bio-based and Applied Economics 5(3): 287-324.

Olper, A., Curzi, D. and Pacca, L. 2014. Do Food Standards Affect the Quality of EU Imports? Economics Letters 122: 233-7.

Orefice, G. 2017. Non-Tariff Measures, Specific Trade Concerns and Tariff Reduction. The World Economy 40(9): 1807-1835.

Reyes, D. 2011. International Harmonization of Product Standards and Firm Heterogeneity in International Trade. Washington DC: The World Bank.

Ronnen, U. 1991. Minimum Quality Standards, Fixed Costs, and Competition. The RAND Journal of Economics 22: 490-504.

Santeramo, F.G. and Lamonaca, E. 2019. The Effects of Non-tariff Measures on Agri-food trade: A Review and Meta-analysis of Empirical Evidence. Journal of Agricultural Economics. 70(3): 595617.

Schuster, M. and Maertens, M. 2013. Do private standards create exclusive supply chains? New evidence from the Peruvian asparagus export sector. Food Policy 43: 291-305

Schuster, M., and Maertens, M. 2015. The Impact of Private Food Standards on Developing Countries' Export Performance: An Analysis of Asparagus Firms in Peru. World Development 66: 208-21.

Schuster, M. and Maertens, M. 2017. Worker empowerment through labour standards. Evidence from the Peruvian agro-export sector. Journal of Development Studies 53(4): 618-637.

Schuster, M. and Maertens, M. 2016. Do private standards benefit workers in horticultural export chains in Peru? Journal of Cleaner Production 112 (4): 2392-2406 
Shapiro, C. 1983. Premiums for High Quality Products as Returns to Reputations, The Quarterly Journal of Economics, 98, 659-679.

Shaked, A. and J. Sutton. 1982. Relaxing Price Competition through Product Differentiation. Review of Economic Studies, 49: 3-13.

Spearot, A.C. 2013. Variable Demand Elasticities and Tariff Liberalization. Journal of International Economics 89 (1): 26-41.

Swinnen, J. 2016. Economics and Politics of Food Standards, Trade, and Development. Agricultural Economics 47 (S1): 7-19

Swinnen, J. and A. Vandeplas. 2011. Rich Consumers and Poor Producers: Quality and Rent Distribution in Global Value Chains. Journal of Globalization and Development, 2 (2), 1-30.

Verhoogen, E., 2008. Trade, Quality Upgrading and Wage Inequality in the Mexican Manufacturing Sector. Quarterly Journal of Economics 123 (2): 489-530.

Vigani, M. and Olper, A. 2014. GM-free private standards, public regulation of GM products and mass media. Environment and Development Economy 19(6): 743-768.

Wilson, J.S. and Otsuki, T. 2003. Food safety and trade: winners and losers in a non-harmonized world, Journal of Economic Integration 18(2): 266-287.

Wilson, J.S. and Otsuki, T. 2004. To spray or not to spray: Pesticides, banana exports, and food safety Food Policy 29(2):131-146.

Wooldridge, J.M. 2010. Econometric Analysis of Cross Section and Panel Data, Second Edition. Boston: MIT Press.

World Bank 2017. Gaining Momentum in Peruvian Agriculture: Opportunities to Increase Productivity and Enhance Competitiveness. Agriculture Global Practice, The World Bank Group, Washington, D.C.

Xiong, B. and Beghin, J.C. 2012. Does European Aflatoxin Regulation Hurt Groundnut Exporters from Africa? European Review of Agricultural Economics 39 (4): 589-609. 
Xiong, B. and Beghin, J.C. 2014. Disentangling Demand-Enhancing and Trade-Cost Effects of Maximum Residue Regulations. Economic Inquiry 52(3): 1190-1203. 
Figure 1. Number of Specific Trade Concerns (STCs) raised on SPS measures

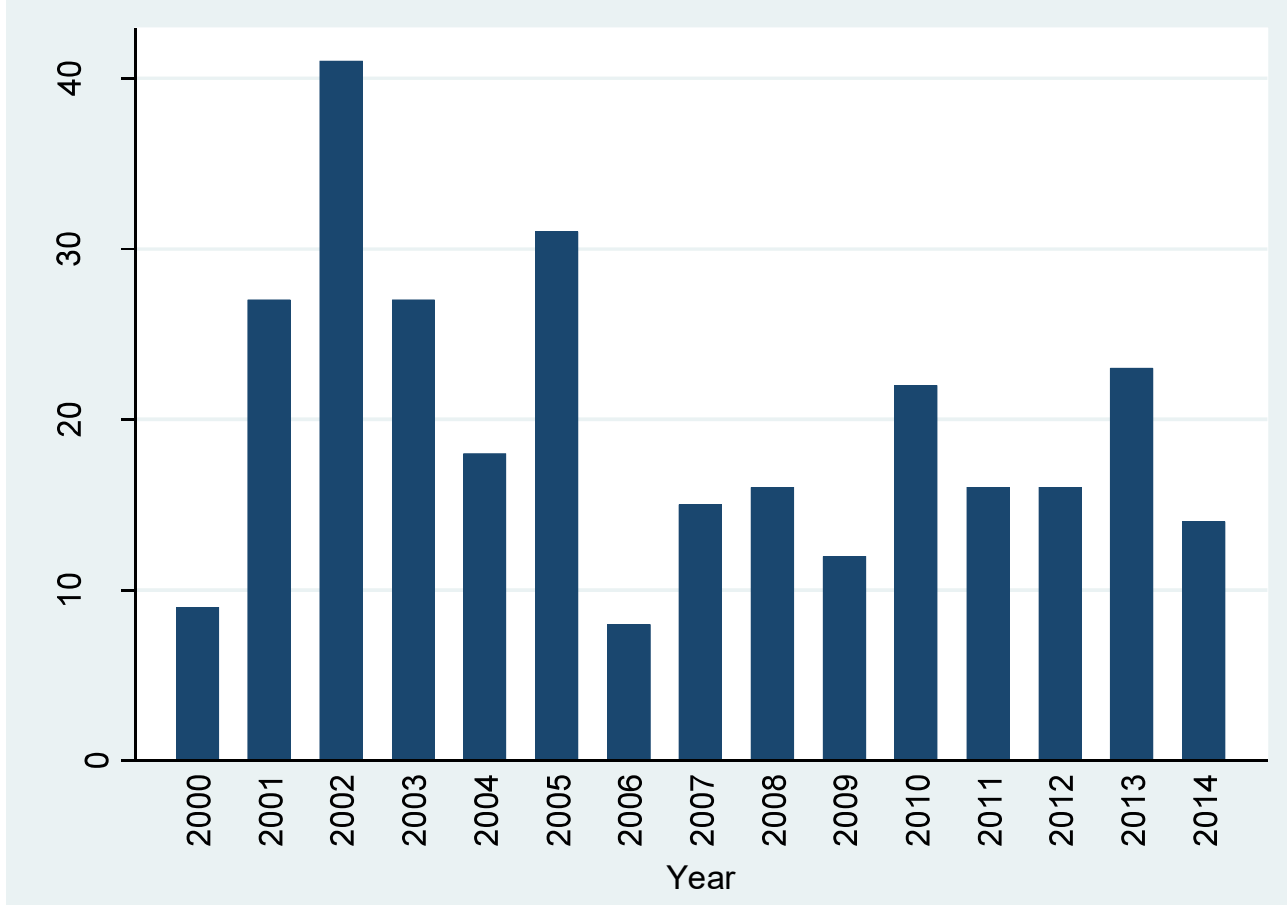

Source: Calculation based on WTO I-TIP database (accessed December 2016). 
Figure 2. Number of new non-tariff measures (NTMs) per year

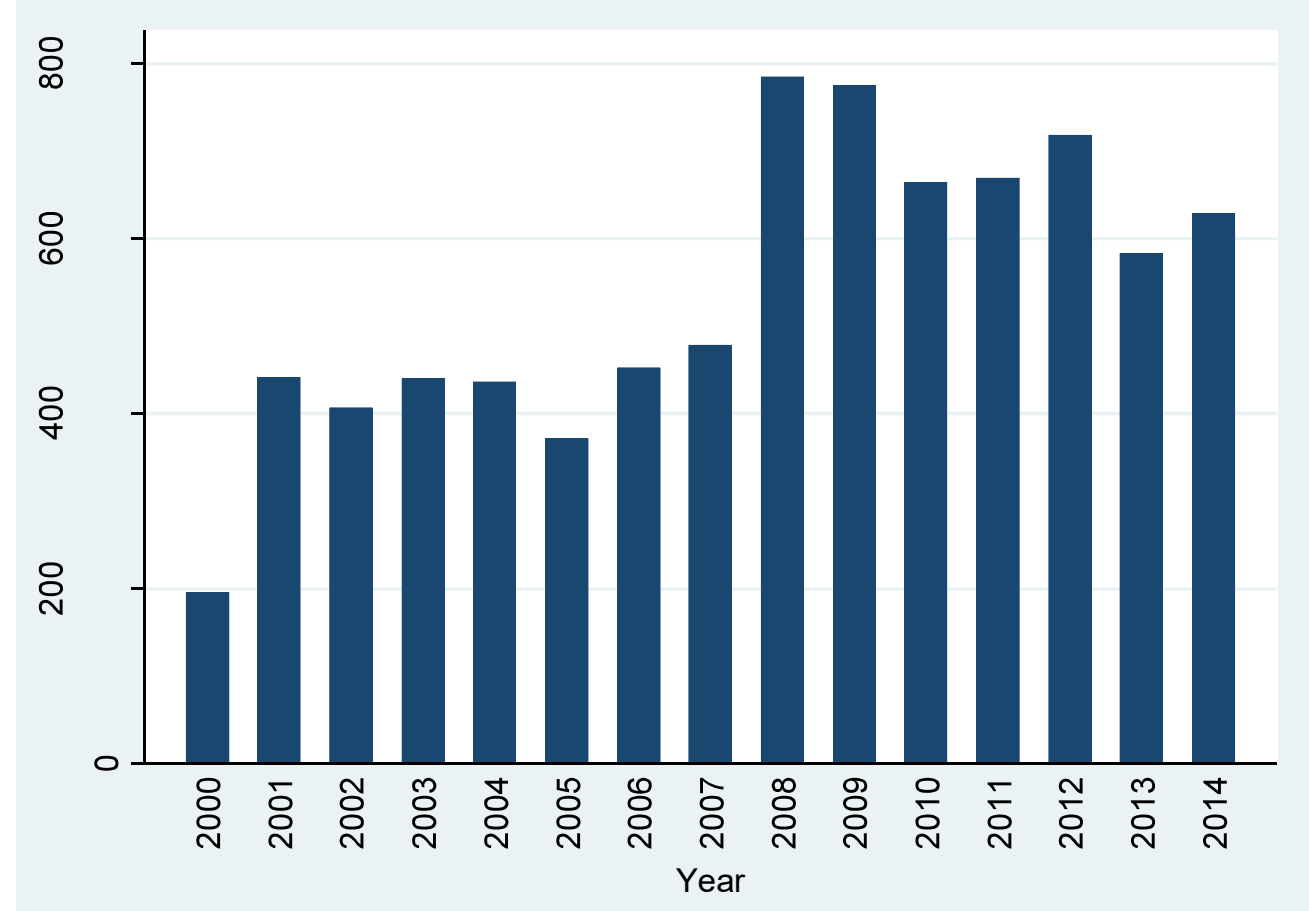

Source: Calculation based on WTO I-TIP database (accessed December 2016). 
Figure 3. Marginal effects of SPS STCs for trade margins and firms' exit, conditional on firms' size
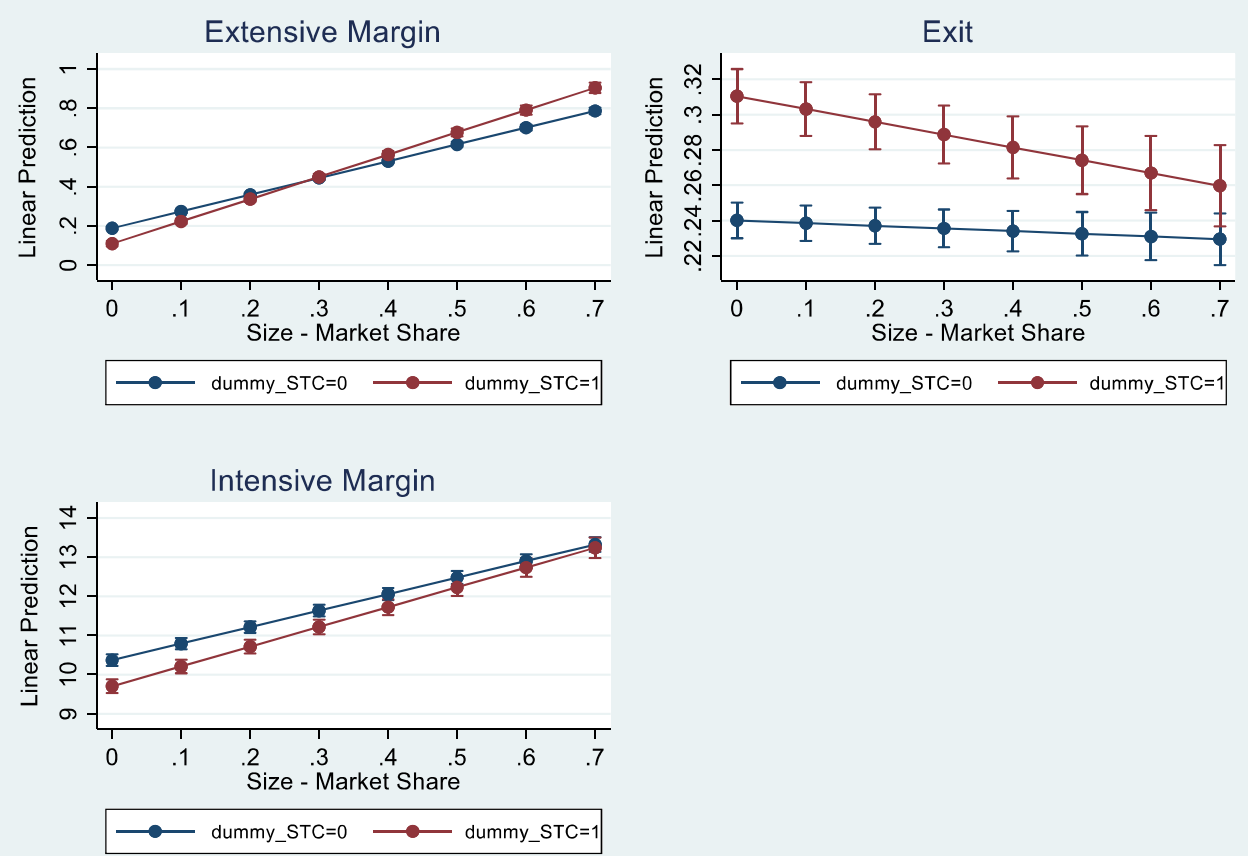

Note: SPS STC marginal effects conditional to firms' size have been computed considering market share as a size variable. The estimated marginal effects for extensive margin, exit probability and intensive margin refer to regression results in Table 2 columns 2,5 and 8 respectively. 
Figure 4. Marginal effects of SPS STCs for price, quality and quality-adjusted price, conditional on firms' size
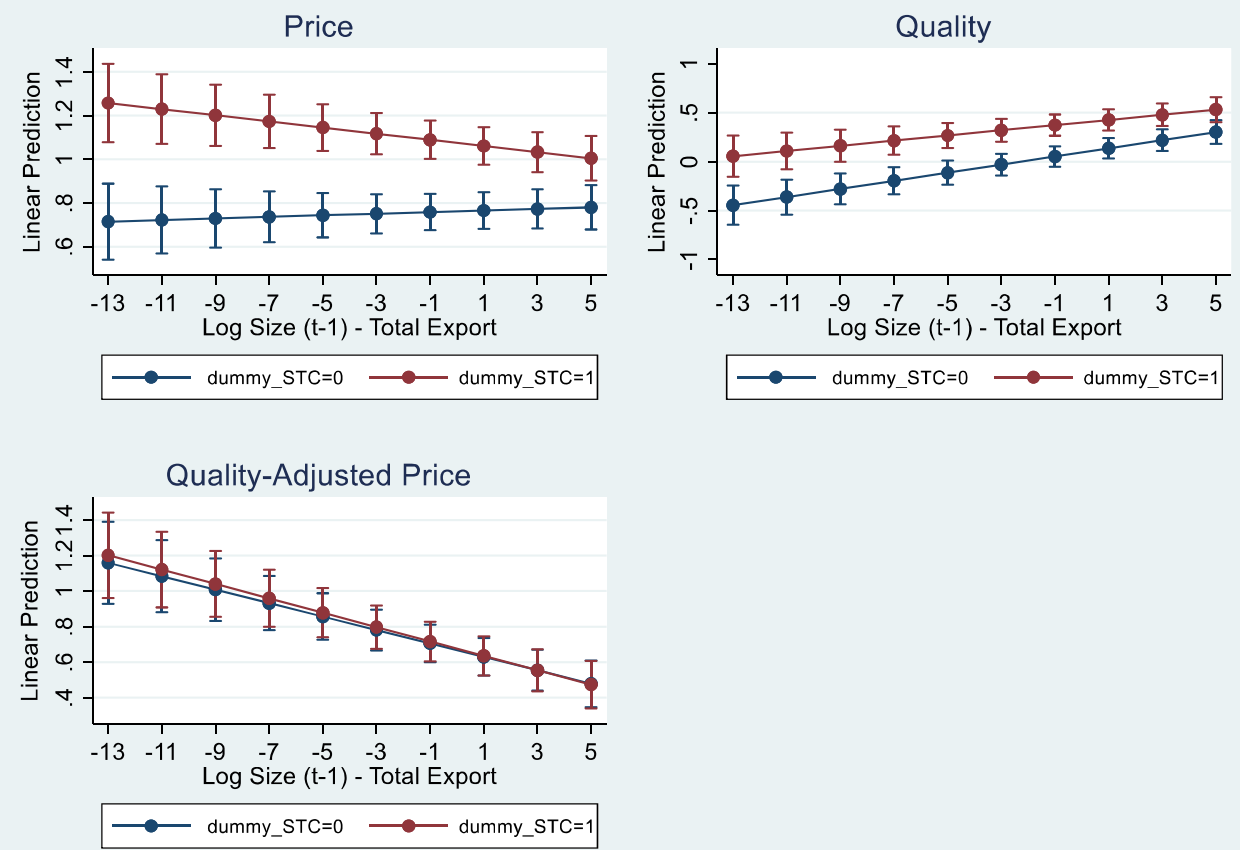

Note: SPS STC marginal effects conditional to firms' size have been computed considering Total export as a size variable. The estimated marginal effects for price, quality and quality-adjusted price refer to regression results in Table 4 columns 1, 4 and 7 respectively. 
Table 1. Summary Statistics of Dependent and Independent Variables

\begin{tabular}{|c|c|c|c|c|c|}
\hline \multicolumn{6}{|c|}{ Dependent Variables } \\
\hline Variable & Obs & Mean & Std. Dev. & Min & Max \\
\hline Extensive margin & 222,532 & 0.21 & 0.41 & 0 & 1 \\
\hline Exit & 222,532 & 0.27 & 0.44 & 0 & 1 \\
\hline (log) Intensive margin & 62,677 & 10.46 & 3.00 & -4.61 & 18.70 \\
\hline (log) Price & 36,584 & 0.91 & 1.02 & -3.51 & 8.69 \\
\hline (log) Quality & 36,584 & 0.24 & 0.68 & -1.81 & 2.66 \\
\hline (log) Quality-adjusted-Price & 36,584 & 0.67 & 1.16 & -4.12 & 8.24 \\
\hline \multicolumn{6}{|c|}{ Control Variables } \\
\hline Variable & Obs & Mean & Std. Dev. & Min & Max \\
\hline Dummy STC & 62,667 & 0.45 & 0.50 & 0 & 1 \\
\hline Dummy SPS & 62,667 & 0.78 & 0.41 & 0 & 1 \\
\hline Dummy TBT & 62,667 & 0.78 & 0.41 & 0 & 1 \\
\hline Dummy border NTM & 62,667 & 0.35 & 0.48 & 0 & 1 \\
\hline Dummy SPS Emergency & 62,667 & 0.03 & 0.16 & 0 & 1 \\
\hline Dummy SPS regular & 62,667 & 0.76 & 0.43 & 0 & 1 \\
\hline (log) Ad valorem tariff & 62,667 & 0.03 & 0.07 & 0 & 1.04 \\
\hline$(\log )$ Size $(t-1)$ & 62,667 & 0.33 & 2.43 & -15.35 & 5.42 \\
\hline$(\log )$ Market share (t-1) & 62,667 & 0.09 & 0.15 & 0 & 0.69 \\
\hline Multi Destination Exporter (Top 10) & 62,667 & 0.02 & 0.15 & 0 & 1 \\
\hline Dummy STC * $\log$ Size $(\mathrm{t}-1)$ & 62,667 & 0.26 & 1.58 & -13.267 & 5.42 \\
\hline Dummy STC $* \log$ Market share $(\mathrm{t}-1)$ & 62,667 & 0.03 & 0.09 & 0 & 0.69 \\
\hline Dummy STC * Multi Destination Exporter (Top 10) & 62,667 & 0.01 & 0.10 & 0 & 1 \\
\hline
\end{tabular}

Note: All variables and data sources are described in the text. 


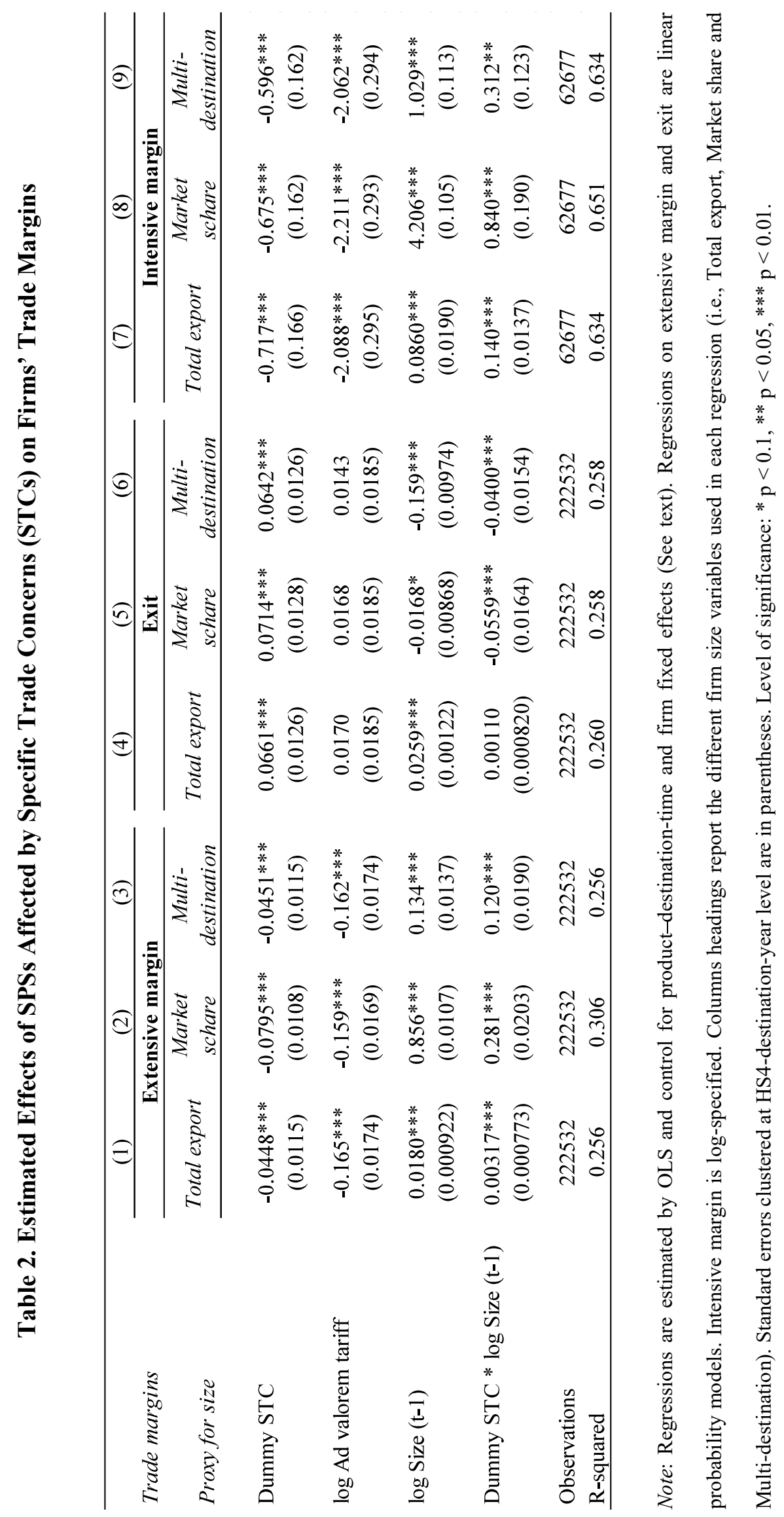


Table 3. Estimated Effects of Different Non-Tariff Measures (NTMs) on Firms'

Extensive Trade Margin, Probability to Exit and Intensive Trade Margin

\begin{tabular}{|c|c|c|c|c|c|c|}
\hline & (1) & (2) & (3) & (4) & $(5)$ & (6) \\
\hline Trade margins & $\begin{array}{c}\text { Extensive } \\
\text { margin }\end{array}$ & $\begin{array}{c}\text { Extensive } \\
\text { margin }\end{array}$ & Exit & Exit & $\begin{array}{c}\text { Intensive } \\
\text { margin }\end{array}$ & $\begin{array}{c}\text { Intensive } \\
\text { margin }\end{array}$ \\
\hline Dummy STC & $\begin{array}{c}-0.052 * * * \\
(0.012)\end{array}$ & $\begin{array}{c}-0.050 * * * \\
(0.012)\end{array}$ & $\begin{array}{c}0.058 * * * \\
(0.013)\end{array}$ & $\begin{array}{c}0.057 * * * \\
(0.013)\end{array}$ & $\begin{array}{c}-0.716^{* * *} \\
(0.166)\end{array}$ & $\begin{array}{c}-0.709 * * * \\
(0.167)\end{array}$ \\
\hline Dummy SPS & $\begin{array}{c}0.024 * * \\
(0.010)\end{array}$ & & $\begin{array}{l}-0.003 \\
(0.009)\end{array}$ & & $\begin{array}{c}0.234 * * \\
(0.109)\end{array}$ & \\
\hline Dummy TBT & $\begin{array}{l}0.032 * \\
(0.018)\end{array}$ & $\begin{array}{c}0.029 \\
(0.018)\end{array}$ & $\begin{array}{c}0.075^{* * *} \\
(0.016)\end{array}$ & $\begin{array}{c}0.076^{* * *} \\
(0.016)\end{array}$ & $\begin{array}{c}0.431^{* *} \\
(0.201)\end{array}$ & $\begin{array}{c}0.429 * * \\
(0.201)\end{array}$ \\
\hline Dummy border NTM & $\begin{array}{c}-0.012 * * \\
(0.005)\end{array}$ & $\begin{array}{c}-0.011^{* *} \\
(0.005)\end{array}$ & $\begin{array}{l}-0.005 \\
(0.005)\end{array}$ & $\begin{array}{l}-0.005 \\
(0.005)\end{array}$ & $\begin{array}{l}-0.105^{*} \\
(0.058)\end{array}$ & $\begin{array}{l}-0.105^{*} \\
(0.058)\end{array}$ \\
\hline Dummy SPS emergency & & $\begin{array}{c}-0.124^{* * *} \\
(0.011)\end{array}$ & & $\begin{array}{c}0.028^{* *} \\
(0.013)\end{array}$ & & $\begin{array}{l}-0.044 \\
(0.142)\end{array}$ \\
\hline Dummy SPS regular & & $\begin{array}{c}0.033^{* * *} \\
(0.010)\end{array}$ & & $\begin{array}{l}-0.005 \\
(0.009)\end{array}$ & & $\begin{array}{c}0.248^{* *} \\
(0.109)\end{array}$ \\
\hline $\log$ Ad valorem tariff & $\begin{array}{c}-0.159^{* * *} \\
(0.017)\end{array}$ & $\begin{array}{c}-0.156^{* * *} \\
(0.017)\end{array}$ & $\begin{array}{c}0.020 \\
(0.019)\end{array}$ & $\begin{array}{c}0.019 \\
(0.019)\end{array}$ & $\begin{array}{c}-2.036^{* * *} \\
(0.299)\end{array}$ & $\begin{array}{c}-2.014 * * * \\
(0.299)\end{array}$ \\
\hline $\log$ Size (t-1) & $\begin{array}{c}0.018 * * * \\
(0.001)\end{array}$ & $\begin{array}{c}0.018^{* * *} \\
(0.001)\end{array}$ & $\begin{array}{c}0.026^{* * *} \\
(0.001)\end{array}$ & $\begin{array}{c}0.026^{* * *} \\
(0.001)\end{array}$ & $\begin{array}{c}0.086^{* * *} \\
(0.019)\end{array}$ & $\begin{array}{c}0.086^{* * *} \\
(0.019)\end{array}$ \\
\hline Dummy STC $* \log$ Size $(\mathrm{t}-1)$ & $\begin{array}{c}0.003 * * * \\
(0.001)\end{array}$ & $\begin{array}{c}0.003 * * * \\
(0.001)\end{array}$ & $\begin{array}{c}0.001 \\
(0.001)\end{array}$ & $\begin{array}{c}0.001 \\
(0.001)\end{array}$ & $\begin{array}{c}0.140^{* * *} \\
(0.014)\end{array}$ & $\begin{array}{c}0.140^{* * *} \\
(0.014)\end{array}$ \\
\hline Observations & 222532 & 222532 & 222532 & 222532 & 62677 & 62677 \\
\hline R-squared & 0.256 & 0.258 & 0.260 & 0.260 & 0.634 & 0.634 \\
\hline
\end{tabular}

Note: Regressions are estimated using OLS and control for product-destination-time and firm fixed effects (see text). Regressions on extensive margin and exit are linear probability models. Intensive margin is log-specified. All regressions in the table use total export as a proxy for firm size. Standard errors clustered at HS4-destinationyear level are in parentheses. Level of significance: * $\mathrm{p}<0.1$, $^{* *} \mathrm{p}<0.05$, *** $\mathrm{p}<0.01$. 
Table 4. Estimated Effects of Different Non-Tariff Measures (NTMs) on Firm-Level Price, Quality and Quality-Adjusted Price

\begin{tabular}{|c|c|c|c|c|c|c|c|c|c|}
\hline & (1) & (2) & (3) & (4) & $(5)$ & (6) & $(7)$ & $(8)$ & (9) \\
\hline & Price & Price & Price & Quality & Quality & Quality & $\begin{array}{c}\text { Quality-adj } \\
\text { Price }\end{array}$ & $\begin{array}{c}\text { Quality-adj } \\
\text { Price }\end{array}$ & $\begin{array}{c}\text { Quality-adj } \\
\text { Price } \\
\end{array}$ \\
\hline Dummy STC & $\begin{array}{c}0.331 * * * \\
(0.086)\end{array}$ & $\begin{array}{c}0.337 * * * \\
(0.084)\end{array}$ & $\begin{array}{c}0.337 * * * \\
(0.083)\end{array}$ & $\begin{array}{c}0.321^{* * *} \\
(0.096)\end{array}$ & $\begin{array}{c}0.323 * * * \\
(0.096)\end{array}$ & $\begin{array}{c}0.323^{* * *} * \\
(0.085)\end{array}$ & $\begin{array}{c}0.010 \\
(0.083)\end{array}$ & $\begin{array}{l}0.015 \\
(0.100)\end{array}$ & $\begin{array}{l}0.014 \\
(0.091)\end{array}$ \\
\hline Dummy SPS & & $\begin{array}{c}0.194 * * * \\
(0.048)\end{array}$ & & & $\begin{array}{c}0.017 \\
(0.035)\end{array}$ & & & $\begin{array}{l}0.177 * * * \\
(0.040)\end{array}$ & \\
\hline Dummy TBT & & $\begin{array}{c}0.263^{* * *} \\
(0.102)\end{array}$ & $\begin{array}{l}0.258^{* *} \\
(0.101)\end{array}$ & & $\begin{array}{l}-0.096 \\
(0.074)\end{array}$ & $\begin{array}{l}-0.096 \\
(0.078)\end{array}$ & & $\begin{array}{l}0.359^{* * *} \\
(0.116)\end{array}$ & $\begin{array}{l}0.354 * * * \\
(0.106)\end{array}$ \\
\hline Dummy border NTM & & $\begin{array}{c}0.034 \\
(0.021)\end{array}$ & $\begin{array}{c}0.033 \\
(0.021)\end{array}$ & & $\begin{array}{c}0.011 \\
(0.018)\end{array}$ & $\begin{array}{c}0.011 \\
(0.020)\end{array}$ & & $\begin{array}{l}0.023 \\
(0.024)\end{array}$ & $\begin{array}{l}0.022 \\
(0.023)\end{array}$ \\
\hline Dummy SPS emergency & & & $\begin{array}{c}0.001 \\
(0.062)\end{array}$ & & & $\begin{array}{c}0.030 \\
(0.049)\end{array}$ & & & $\begin{array}{l}-0.028 \\
(0.055)\end{array}$ \\
\hline Dummy SPS regular & & & $\begin{array}{c}0.206^{* * *} \\
(0.048)\end{array}$ & & & $\begin{array}{c}0.016 \\
(0.034)\end{array}$ & & & $\begin{array}{l}0.190^{* * * *} \\
(0.042)\end{array}$ \\
\hline $\log$ Ad valorem tariff & $\begin{array}{c}-0.591 * * * \\
(0.106)\end{array}$ & $\begin{array}{c}-0.660 * * * \\
(0.108)\end{array}$ & $\begin{array}{c}-0.647^{* * * *} \\
(0.108)\end{array}$ & $\begin{array}{c}0.481^{* * *} \\
(0.095)\end{array}$ & $\begin{array}{c}0.468 * * * \\
(0.098)\end{array}$ & $\begin{array}{c}0.467 * * * \\
(0.096)\end{array}$ & $\begin{array}{c}-1.072^{* * *} \\
(0.119)\end{array}$ & $\begin{array}{l}-1.128^{* * *} \\
(0.118)\end{array}$ & $\begin{array}{l}-1.114^{* * *} \\
(0.117)\end{array}$ \\
\hline $\log$ Size $(t-1)$ & $\begin{array}{c}0.005 \\
(0.006)\end{array}$ & $\begin{array}{c}0.005 \\
(0.006)\end{array}$ & $\begin{array}{c}0.005 \\
(0.006)\end{array}$ & $\begin{array}{c}0.046^{* * *} \\
(0.006)\end{array}$ & $\begin{array}{c}0.046^{* * *} \\
(0.006)\end{array}$ & $\begin{array}{c}0.046^{* * *} \\
(0.006)\end{array}$ & $\begin{array}{c}-0.041^{* * *} \\
(0.007)\end{array}$ & $\begin{array}{l}-0.041^{* * *} \\
(0.008)\end{array}$ & $\begin{array}{l}-0.041^{* * *} \\
(0.007)\end{array}$ \\
\hline Dummy STC $* \log$ Size $(\mathrm{t}-1)$ & $\begin{array}{c}-0.020 * * * \\
(0.005)\end{array}$ & $\begin{array}{c}-0.019 * * * \\
(0.005)\end{array}$ & $\begin{array}{c}-0.020 * * * \\
(0.005)\end{array}$ & $\begin{array}{c}-0.026^{* * * *} \\
(0.004)\end{array}$ & $\begin{array}{c}-0.026^{* * *} \\
(0.004)\end{array}$ & $\begin{array}{c}-0.026^{* * *} \\
(0.004)\end{array}$ & $\begin{array}{c}0.006 \\
(0.005)\end{array}$ & $\begin{array}{l}0.007 \\
(0.006)\end{array}$ & $\begin{array}{l}0.006 \\
(0.005)\end{array}$ \\
\hline Observations & 36584 & 36584 & 36584 & 36584 & 36584 & 36584 & 36584 & 36584 & 36584 \\
\hline R-squared & 0.815 & 0.815 & 0.816 & 0.407 & 0.407 & 0.407 & 0.731 & 0.731 & 0.732 \\
\hline
\end{tabular}

Note: Regressions are estimated using OLS and control for product-destination-time and firm fixed effects (see text). Price, quality and quality adjusted price are log-specified. Standard errors clustered at HS4-destinationyear level are in parentheses. Since quality is an estimated variable, regressions in columns from 4 to 9 with quality and quality-adjusted prices as dependent variables have a bootstrapped standard error based on 100replications. Level of significance: $* \mathrm{p}<0.1,{ }^{* *} \mathrm{p}<0.05,{ }^{* * *} \mathrm{p}<0.01$. 


\section{Table 5. Estimated Effects of Different Non-Tariff Measures (NTMs) on Firm-Level Price and Quality for Firms with Different Levels of Product Differentiation}

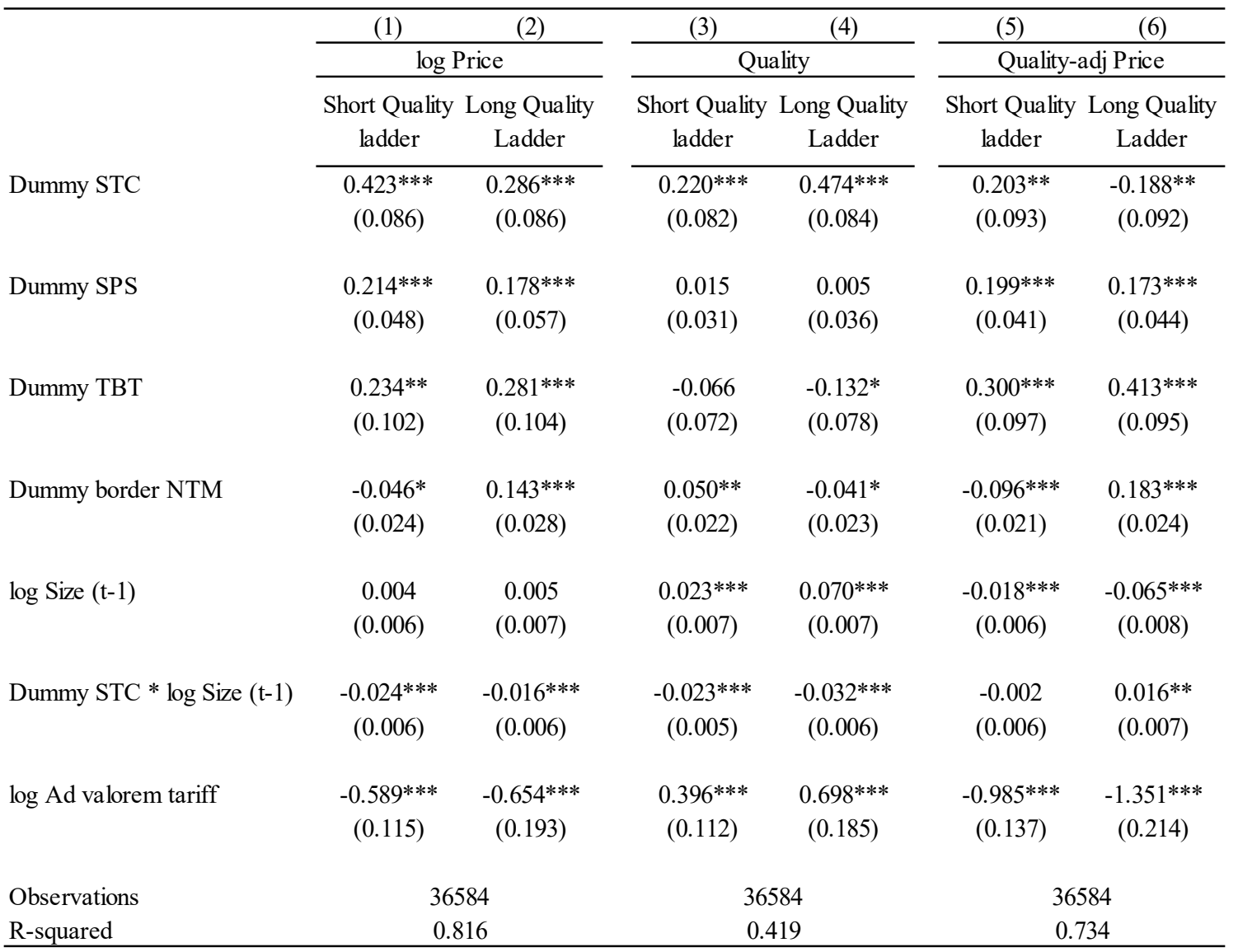

Note: The sample has been divided according to the level of product differentiation, as indicated by the quality ladder (see text for further details). All regressions are estimated using OLS and control for product-destinationtime and firm fixed effects (see text). Price, quality and quality-adjusted price are log-specified. Standard errors clustered at HS4-destination-year level are in parentheses. Since quality is an estimated variable, regressions with quality and quality-adjusted prices as dependent variables have a bootstrapped standard error based on 100replications. Level of significance: $* \mathrm{p}<0.1, * * \mathrm{p}<0.05, * * * \mathrm{p}<0.01$. 